家鬼骨鹃組織液体培養法による鉄, 銅及び

コバルトの増血作用に関する研究

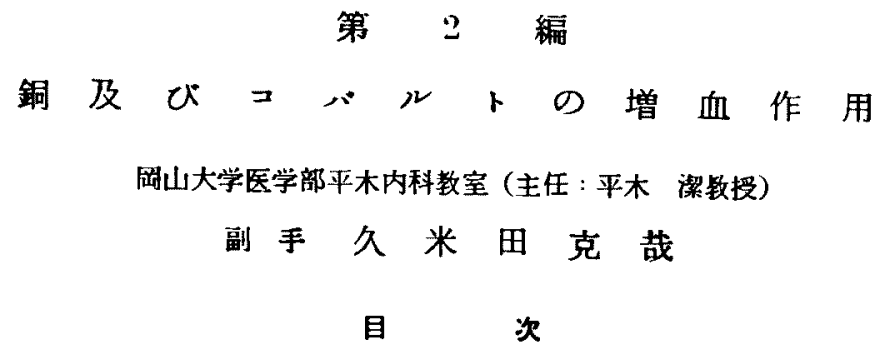

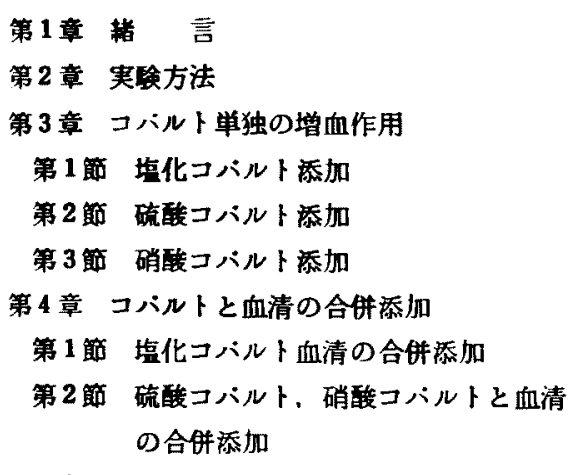

第5章 鉄剂とコバルトの合併添版

第1節 グルコン酸第 2 鉄，㹂化コハルトD 添加

第 2 筑 硫酸第 1 鉄，培化コバルトの添加

第 3 節 グルコン酷第 2 鉄, 硫酸コバルトの

\section{算 1 章藉言}

1929年 Waltner and Waltner ${ }^{\text {(9) }}$ によりラクテの 食触化少星のコバルトを添加すれは著明な赤血球 增多应学起することが発見されて以来，多くの学 者により犬，家鬼等に於てる同様の事寒が確認き れた. 又1948年には Rickes, Brink63) 等により V. B12 の分子中にコバルトの存在することが確認 されて諸家の注目するところとなり，近来は賽血治 暴の一端に盛にコハルトが利用されつつある. 而 してコバルトは铁と異り，之を正常な血液状隹にあ る動物に用いた場合にる增血を来す特徽る有してい るが，增血作用の本態に関しては Orten3762) - - 派, 鉿木798001) 等諸家の研究が見られるとはいえその 詳練化ついてはなお不明の点が多い。

次銅は 19 世紀始めより動・植物体内に存する
添加

第 4 節 クルコン醅第 2 鉄, 硝酸コパルト 添压

第6 章 銅の增血作用

第 1 節 硫醂銅添加

第 2 笛 塭化銅添加

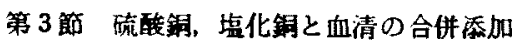

第 4 䬦 クルコン醉第 2 鉄、碝酸鉰の合併添 加

第 5 節 クルコン酸第 2 鉄，盐化銅の合併添 加

第 7 章 鉄、铜，コハルトの3者同時添加

第 8 章 総括及び考按

第 9 章 結語

ことが知られ，1838年には Devergie \& Hervey9) に より人体租桠中に, 1849 年には Deschamps) に

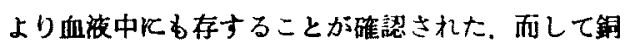
は下等動物に於て，恰も高等動钩の Hb 分子中の 鉄の如くへモチアニンなる血色装の一成分として存 在し呼吸に関係していることが知られている以外， その生理的意桡に関しては不明であつた，然るに近 年に至り铜は生体内に於て種々の重要な生理的役割 を演じていることが断次かとなり，殊に之が貫血 恢復に対し有效なことが知られるに及び一般学者 の注目を惹くようになつた。即ち1928年以来, Wadde183), Titus, Cave \& Hughes ${ }^{83}$ ) 等により釷

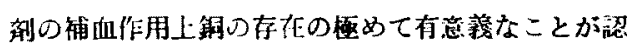
められ, Inoue \& Flinn31), Harque20), Heally \& Hill 等も同様に Hb 生成上鉰は重要な役割考演 じることを記述し、久本判に於ても服部23)，桜井66 
等は臨床上鉄，銅併用療法を行つて良好な成縝を收 めている，而してその増血機枟に関しては，赤血球 新生飞対し刺戙る与えると共に，鉄を $\mathrm{Hb} の \mathrm{Hem}$ 核中飞導入㚲しめる触媒的作用を営むことが近時明 がされている.

私は以上のコバルト及び銅の增血作用を更飞端的

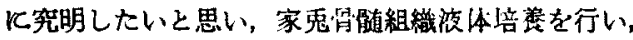
之に直接コバルト，銅を添加し，卯か興味ある事寒 を得たので兹に報告する。

\section{第2章实酸方法}

前編に於て述へた如く，健康幼弱家兔より骨髄絊 胞孚游液をつくり，之にコバト．銅の各塩類水溶

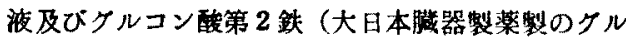
フェリコン）を添加，Warburg 氏恒温慒て振透培 養し， 4 及び 8 時間後その一部をとり計测を行つた。 実験方法の詳紐とついては第 1 編に述べたので省略 する。

\section{第3 章 コパルト単独の增血作用}

第 節 塭化コパルト添加（第 $1 ， 2$ 表，第 1 ， 2四)

表儿示す如く赤血球数は $5 \mathrm{mg}$ 添加では 4 時問で $-13.3 \%, 10 \mathrm{mg}$ 添加では同しく-35.996 隇少し， 対照が21.7\%の增加を示したのに对し，明か悪い 結果を示した， 8 時間では $5 \mathrm{mg} ， 10 \mathrm{mg}$ 共更に減 少し，对照も-42.3\%と大きく減少した。 Hb 量は 同しく 4, 8 時間共に培盖前より诚少しているが， $10 \mathrm{mg}$ 添加の場合忙 8 時間で 4 時間上りるやや增加 している. 対照も時間と共核減少するが添加例飞比 第1表 塩化コバルト添加（1）

\begin{tabular}{|c|c|c|c|c|}
\hline & & 培趇前 & 4 洔間 & 8 時間 \\
\hline 赤血球数 (104) & $\begin{array}{r}5 \mathrm{mg} \\
10 \mathrm{mg} \\
\text { 対 }\end{array}$ & $\begin{array}{l}12.8 \\
11.4 \\
12.0\end{array}$ & $\begin{array}{r}11.1 \\
7.3 \\
14.6\end{array}$ & $\begin{array}{l}8.8 \\
5.6 \\
6.9\end{array}$ \\
\hline 赤血球增加膟（\%) & $\begin{array}{r}5 \mathrm{mg} \\
10 \mathrm{mg} \\
\text { 対 }\end{array}$ & $\begin{array}{l}- \\
-\end{array}$ & $\left|\begin{array}{r}-13.3 \\
-35.9 \\
21.7\end{array}\right|$ & $\mid \begin{array}{l}-31.2 \\
-50.8 \\
-42.3\end{array}$ \\
\hline $\mathrm{Hb}$ 量 $(\mathrm{mg} / \mathrm{dl})$ & $\begin{array}{r}5 \mathrm{mg} \\
10 \mathrm{mg} \\
\text { 対 }\end{array}$ & $\begin{array}{l}430 \\
420 \\
385\end{array}$ & $\begin{array}{l}290 \\
190 \\
325\end{array}$ & $\begin{array}{l}210 \\
230 \\
290\end{array}$ \\
\hline Hb 增加量 (" & $\begin{array}{r}5 \mathrm{mg} \\
10 \mathrm{mg} \\
\text { 対 }\end{array}$ & $\begin{array}{l}- \\
- \\
-\end{array}$ & $\begin{array}{l}-140 \\
-230 \\
-60\end{array}$ & $\begin{array}{r}-220 \\
-190 \\
-95\end{array}$ \\
\hline
\end{tabular}

第 2 表 塩化コパルト源加（2）

\begin{tabular}{|c|c|c|c|c|}
\hline & & 培药前 & 4 時間 & 8 時間 \\
\hline 赤血球数 (104) & $\begin{array}{r}0.3 \mathrm{mg} \\
1 \mathrm{mg} \\
\text { 対 }\end{array}$ & $\begin{array}{l}41.7 \\
32.4 \\
36.6\end{array}$ & $\begin{array}{l}35.8 \\
35.3 \\
37.8\end{array}$ & \begin{tabular}{|l|l}
39.5 \\
34.7 \\
36.8
\end{tabular} \\
\hline 赤血球增加率（\%） & $\begin{array}{c}0.3 \mathrm{mg} \\
1 \mathrm{mg} \\
\text { 対 }\end{array}$ & $\begin{array}{l}- \\
- \\
-\end{array}$ & \begin{tabular}{|r|}
-11.8 \\
8.9 \\
3.3
\end{tabular} & \begin{tabular}{|r}
-5.3 \\
7.1 \\
0.7
\end{tabular} \\
\hline Hb 量 $(\mathrm{mg} / \mathrm{dl})$ & $\begin{array}{c}0.3 \mathrm{mg} \\
1 \mathrm{mg} \\
\text { 対 }\end{array}$ & $\begin{array}{l}615 \\
615 \\
615\end{array}$ & $\begin{array}{l}340 \\
450 \\
405\end{array}$ & $\begin{array}{l}450 \\
500 \\
500\end{array}$ \\
\hline 百b 增加量 (" ") & $\begin{array}{c}0.3 \mathrm{mg} \\
1 \mathrm{mg} \\
\quad \text { 対 }\end{array}$ & $\begin{array}{l}- \\
- \\
-\end{array}$ & $\begin{array}{l}-275 \\
-165 \\
-210\end{array}$ & $\begin{array}{l}-165 \\
-115 \\
-115\end{array}$ \\
\hline
\end{tabular}

第 1 図 塩化コバルト添加（1）

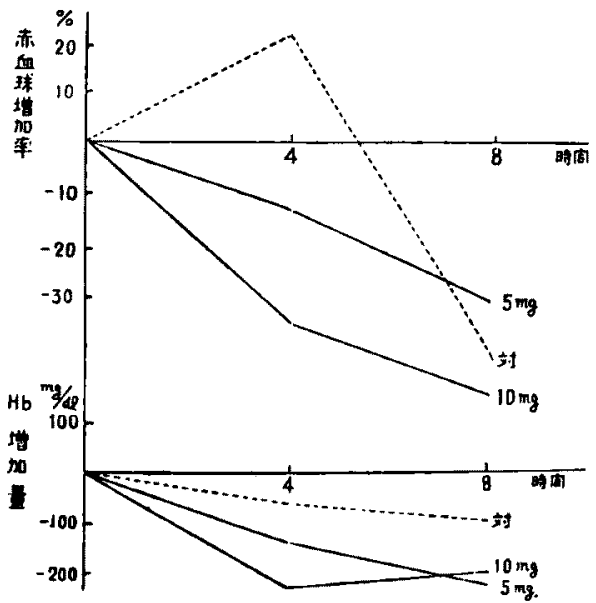

第 2 図 塩化コバルト添加 (2)

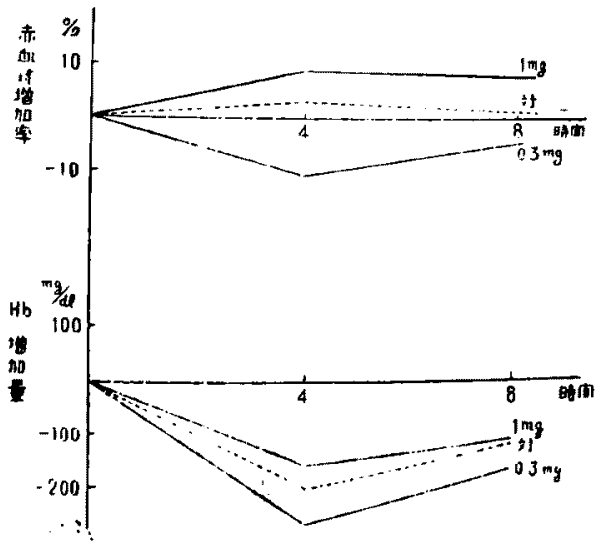


して象てをる。

次火来加暠を減少し $1 \mathrm{mg}$ 及び $0.3 \mathrm{mg}$ とする と，1mg て赤血球增加率が初めて 4,8 時間共対

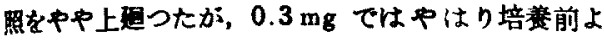
り却つて城少した. Hb 量は何れる4 時間で $200 \mathrm{mg}$ 内外の減少，8時間ては之より僅が增加し $150 \mathrm{mg}$ 前後の成少を示し，ほほ対照と等しい，以上塩化コ ハルト水容波の直接添加では諸氏の静注或は経口的 投与の洁果と相反し， $1 \mathrm{mg}$ て僅か、赤血球增加率 が対照より大となる他はすへて骨随に対し掌る障害 的な作用を及ほすよ5に思われる。

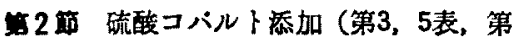
3, 5 図)

$5 \mathrm{mg}$ 及び $10 \mathrm{mg}$ を添加するК，5 mgで 4 時間 11.7\%，8時間21.1\%，10 mgでは 4 時間33.4\%， 8 時間26.1\%と対照の2.196及び-0.2\%比し著明 な赤血球增加事を示した，又 $1 \mathrm{mg}$ 添加では4時間 て32.0\%，8時間20.9％と $10 \mathrm{mg}$ の場合と同様な 增加宗示す. 之に対し $\mathrm{Hb}$ 量は $5,10 \mathrm{mg}$ 共 4 時間 及ひ 8 時間で $600 \mathrm{mg}$ 以上の減少を来し，対照の平 均 $250 \mathrm{mg}$ の減少を大きく上通つた，又 $1 \mathrm{mg}$ 添加 で 4, 8 跱間共培養前に比し大きい変動は見られ ない，又対照とる大差をみない，何れにしても硫酸 コバルトの加は，諸家のい5如く甚しい赤血球增 多を意起するか， Hb 量は逆に却つて大きく減少す るか又著しい变化なく，即ち明かな低色性の增血 作用を認めた。

第 3 丝硝酸コバルト添加（第4，5表，第 4, 5园)

赤血球增加率は $5 \mathrm{mg}$ 添加では 4 時間で堌隇なく， 第 3 表 硫酸コパルト添加（1）

\begin{tabular}{|c|c|c|c|c|}
\hline & & 培養前 & 4 時間 & 8 時間 \\
\hline \multirow{3}{*}{ 赤血球数 (104) } & $5 \mathrm{mg}$ & 18.0 & 20.1 & 21.8 \\
\hline & $10 \mathrm{mg}$ & 18.0 & 24.0 & 22.7 \\
\hline & 対 & 21.0 & 23.1 & 20.8 \\
\hline \multirow{3}{*}{ 赤血球增加事（\%) } & $5 \mathrm{mg}$ & - & 11.7 & 21.1 \\
\hline & $10 \mathrm{mg}$ & - & 33.4 & 26.1 \\
\hline & 対 & - & 2.1 & -0.2 \\
\hline \multirow{3}{*}{ Hb $(m g / d l)$} & $5 \mathrm{mg}$ & 1345 & 740 & 670 \\
\hline & $10 \mathrm{mg}$ & 1345 & 500 & 740 \\
\hline & 対 & 740 & 500 & 480 \\
\hline \multirow{3}{*}{ Hb 增加早（"） } & $5 \mathrm{mg}$ & - & -605 & -675 \\
\hline & $10 \mathrm{mg}$ & - & -845 & -605 \\
\hline & 対 & - & -240 & -260 \\
\hline
\end{tabular}

第4表 硝酸コバルト添加（1）

\begin{tabular}{|c|c|c|c|c|}
\hline & & 培盖前 & 4 時間 & 8 時間 \\
\hline \multirow{3}{*}{ 赤血 球 数 (104) } & $5 \mathrm{mg}$ & 25.5 & 25.5 & 15.9 \\
\hline & $10 \mathrm{mg}$ & 18.1 & 20.1 & 15.0 \\
\hline & 対 & 16.3 & 16.7 & 12.3 \\
\hline \multirow{3}{*}{ 赤血球增加率 (象) } & $5 \mathrm{mg}$ & - & 0 & -37.6 \\
\hline & $10 \mathrm{mg}$ & - & 11.0 & -17.1 \\
\hline & 対 & - & 2.5 & -24.5 \\
\hline \multirow{3}{*}{$\mathrm{Hb}$ 量 $(\mathrm{mg} / \mathrm{dl})$} & $5 \mathrm{mg}$ & 240 & 220 & 210 \\
\hline & $10 \mathrm{mg}$ & 290 & 390 & 310 \\
\hline & 対 & 290 & 330 & 230 \\
\hline \multirow{3}{*}{ Hb 增加量 (" ") } & $5 \mathrm{mg}$ & - & -20 & -30 \\
\hline & $10 \mathrm{mg}$ & - & 100 & 20 \\
\hline & 対 & - & 40 & -60 \\
\hline
\end{tabular}

第 5 表 硝酸コバルト，硫酸コパルト添加（2）

\begin{tabular}{|c|c|c|c|c|}
\hline & & |培祖前 & 4 時間 & 8 時間 \\
\hline \multirow{3}{*}{ 赤血球数 (104) } & 硝コ.1 mg & 16.0 & 19.8 & 15.6 \\
\hline & 犊コ.1 mg & 17.2 & 22.7 & 20.8 \\
\hline & 対 & 18.7 & 19.9 & 15.6 \\
\hline \multirow{3}{*}{ 赤血球增加率(象) } & 硝コ.1 mg & - & 23.7 & -2.5 \\
\hline & 硫コ.1 mg & - & 32.0 & 20.9 \\
\hline & 対 & - & 6.5 & -16.5 \\
\hline \multirow{3}{*}{ Hb $(\mathrm{mg} / \mathrm{dl})$} & 硝コ.1 mg & 270 & 290 & 170 \\
\hline & 硫 $=.1 \mathrm{mg}$ & 325 & 300 & 250 \\
\hline & 対 & 250 & 260 & 190 \\
\hline \multirow{3}{*}{ Hb 增加是 ("I) } & 硝コ.1 mg & - & 20 & -100 \\
\hline & 硫コ.1 mg & - & -25 & -75 \\
\hline & 対 & - & 10 & -60 \\
\hline
\end{tabular}

第3困 酼酸コハルト添加（1）

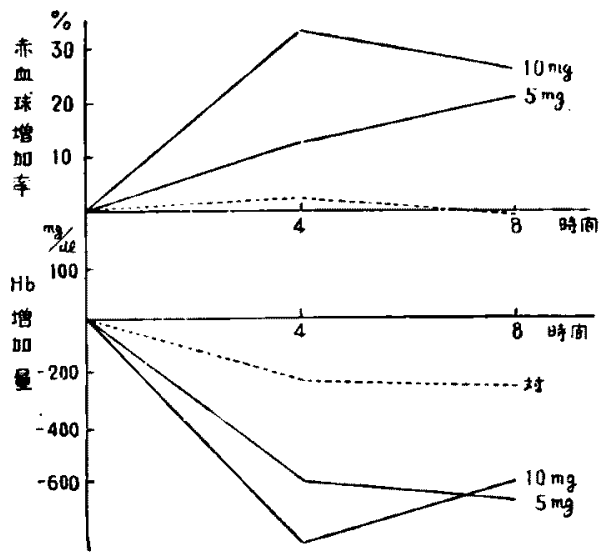


第 4 因硝酸コパルト添加 (1)

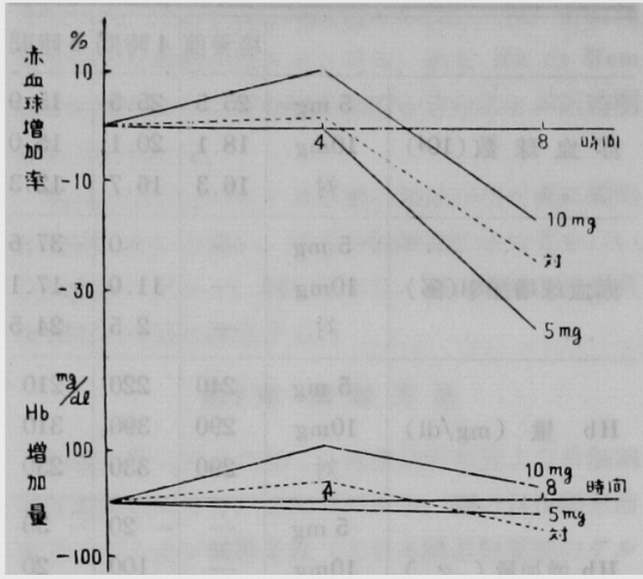

第 5 図硝酸コパト，硫酸コバルト添加 (2)

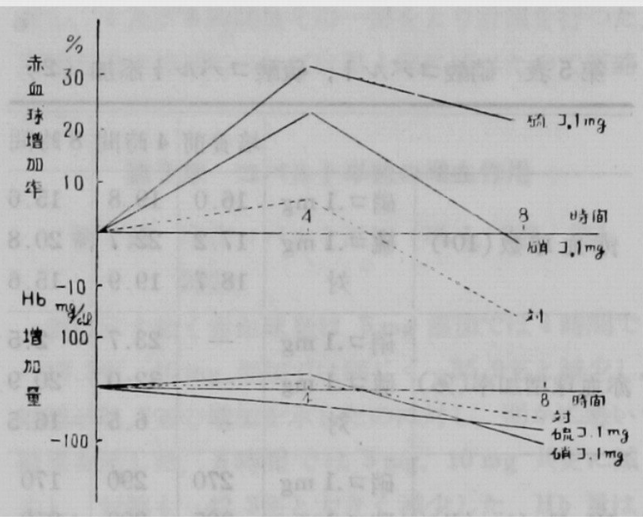

8 時間では著明に隇少し共に対照よりやや悪いが， $10 \mathrm{mg}$ 添加では 4 時間で11\%の増加を示し，対照の 堌加率2.5\%に比しかなりよい. 8 時間では $5 \mathrm{mg} の$ 場合の如く 17.196 减少を示すが対照の24.5\%の減 少よりやや軽度である. 次飞 $1 \mathrm{mg}$ では先ず23.7\% と大きく增加，次で減少し培美前よりごく僅か減少 するが，対照の 4 時間 6.5\%增加，8時間 $16.5 \%$ の 減少に比し明かに差をみる。

次に Hbの増加をみると $5 \mathrm{mg}$ では 4 時間 $-20 \mathrm{mg}$ ， 8 時間-30 mg と僅か減少してゆくが対照では夫 « $40 \mathrm{mg}$ 增, $-60 \mathrm{mg}$ 減となり, 即ち 4 時間では 対照より增加がやや悪く8時間でははほ同様となる。 然ると $10 \mathrm{mg}$ 添加では 4,8 時間共 $100 \mathrm{mg}$ 及び $20 \mathrm{mg}$ の增加となり夫ょ対照より大である. 次に $1 \mathrm{mg}$ 添加では 4 時間で $20 \mathrm{mg}$ 增加しほほ対照と 同様であり，8時間では逆に $100 \mathrm{mg}$ 减少となり対 照より少し悪い. 以上硝酸コパトでは $1 \mathrm{mg}$ 及び $10 \mathrm{mg}$ の添加で赤血球增多を起すか $5 \mathrm{mg}$ では変化 なく, 又 Hb 量は硫酸コパト，塩化コハルトと
異り，10 mg で対照よりやや增加を示し，赤血球の 增加とほほ平行するが，5 mg，1 mg 添加では対 照より幾分隇少を示し赤血球増加率と较べて劣り。 やはり所謂低色性の増血作用がみられる。

\section{第4章コバルト，血零の合併添加}

第 1 第塩化コパル．血清の合併添加 （第 6 表，第 6 図）

血清は第 1 編鉄剂の実験の場合と同様健康家鬼よ り無菌的に採取し，塩化コバルト $1 \mathrm{mg}$ 及び $5 \mathrm{mg}$

第 6 表 塩化コパルト血清添加

\begin{tabular}{|c|c|c|c|c|}
\hline & & 培美前 & 4 時間 & 8 時間 \\
\hline \multirow{3}{*}{ 赤血球数 (104) } & 马. $1 \mathrm{mg}+$ 血 & 7.9 & 9.3 & 8.3 \\
\hline & $=.5 \mathrm{mg}+$ 血 & 8.1 & 7.7 & 8.7 \\
\hline & 対 & 5.6 & 8.3 & 8.4 \\
\hline \multirow{3}{*}{$\begin{array}{r}\text { 赤血球增加率 } \\
(\mathscr{6})\end{array}$} & J. $1 \mathrm{mg}+$ 血. & - & 17.7 & 5.1 \\
\hline & 马. $5 \mathrm{mg}+$ 血. & - & -4.9 & 7.4 \\
\hline & 対 & - & 48.2 & 50.0 \\
\hline \multirow{3}{*}{$\mathrm{Hb}(\mathrm{mg} / \mathrm{dl})$} & ב. $1 \mathrm{mg}+$ 血 & 290 & 190 & 90 \\
\hline & ב. $5 \mathrm{mg}+$ 血 & 140 & 190 & 45 \\
\hline & 対 & 190 & 190 & 90 \\
\hline \multirow{3}{*}{ Hb增加量 (" ) } & ב. $1 \mathrm{mg}+$ 血 & - & -100 & -200 \\
\hline & J. $5 \mathrm{mg}$ +血 & - & 50 & -95 \\
\hline & 対 & - & 0 & -100 \\
\hline
\end{tabular}

第 6 図 嗑化コパルト+血清添加

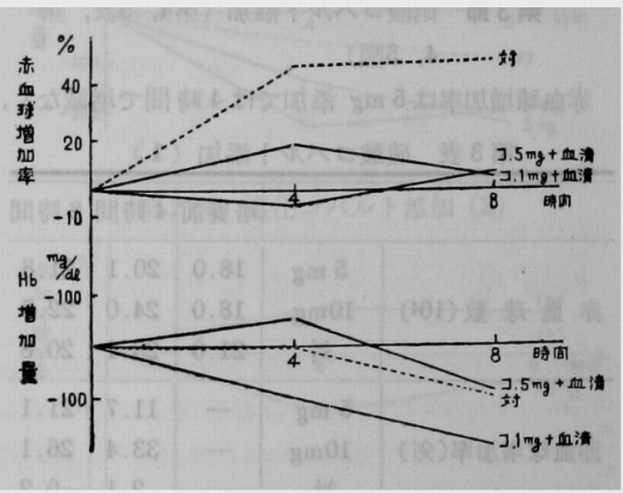

に夫々 $0.3 \mathrm{cc}$ 宛添加した.

先つ $5 \mathrm{mg}$ 添加の場合, 赤血球增加率は 4 時間で $-4.9 \% ， 8$ 時間で 7.4\%的止まり対照の夫ネ 48.2 \%, 50.0\%に比し甚しく劣り単独添加の場合と何等 変化が見られない，次飞 $1 \mathrm{mg}$ の場合は 4 時間で 17.7\%，8時間で5.1\%の增加を示すがやはり対照 の增加率とは明加劣り, 更にこの場合は単独添加 
$1 \mathrm{mg}$ で赤血球增加率が対照よりやや大であると反 対の㟷果を示した. 次に Hb 量の関係をみると $5 \mathrm{mg}$ 添加ては 4 時間て対照の増減0K対し僅かに $50 \mathrm{mg}$ の增加を示し，8時間では対照と同じく $100 \mathrm{mg} の$ 茾少を示し，単独添加で 4,8 時間共対照より $\mathrm{Hb}$ 增加が悪いのに対し，血清添加が良効をるたらす如 く見える. 然るK $1 \mathrm{mg}$ 添加では常に Hb 量は対照 より减少し単独添加の場合より悪い。

以上聕化コパルト造血効果に対し，血清合併添 加の站果市不定であるが，少く共クルコン酸第 2 鉄 (以下グ）の場合の如く明かにコハハルト増血作用 を助ける如き結果は見られない。

期 2 硫酸コパルト，硝酸コハルトと血 清の合併添加（以下硫コ., 硝コ.)

硫コ., 硝コ.各ヶ $1 \mathrm{mg}$ K血清 $0.3 \mathrm{cc}$ を合併添加し た. 赤血球增加率は両者共に著しく大となり，4 時

第 7 表 硫酸コパルト，硝酸コハルトト+血清添加

\begin{tabular}{|c|c|c|c|c|}
\hline & & 培椉 & 4 時間 & 8 時間 \\
\hline 赤血球数 (104) & $\left\{\begin{array}{c}\text { 硫コ.+血. } \\
\text { 硝コ +血. } \\
\text { 対 }\end{array}\right.$ & $\begin{array}{l}6.0 \\
6.1 \\
7.2\end{array}$ & $\begin{array}{r}11.4 \\
10.2 \\
8.6\end{array}$ & $\begin{array}{r}10.8 \\
11.9 \\
7.4\end{array}$ \\
\hline 赤血球增加率(\%) & $\begin{array}{c}\text { 硫コ.+血. } \\
\text { 硝コ.+血. } \\
\text { 対 }\end{array}$ & $\begin{array}{l}- \\
- \\
-\end{array}$ & $\begin{array}{l}90.0 \\
67.2 \\
19.4\end{array}$ & $\begin{array}{r}80.0 \\
95.1 \\
3.3\end{array}$ \\
\hline H b 量 (mg/dl) & $\mid \begin{array}{c}\text { 硫コ.+血. } \\
\text { 硝コ.+血. } \\
\text { 対 }\end{array}$ & $\begin{array}{l}1470 \\
1345 \\
1200\end{array}$ & $\begin{array}{l}1230 \\
1200 \\
1270\end{array}$ & $\begin{array}{r}820 \\
1295 \\
1150\end{array}$ \\
\hline Hb 增加量（"） & $\left\{\begin{array}{c}\text { 硫コ.+血. } \\
\text { 硝コ.+血. } \\
\text { 対 }\end{array}\right.$ & $\begin{array}{l}- \\
-\end{array}$ & $\begin{array}{r}-240 \\
-145 \\
20\end{array}$ & $\begin{array}{l}-650 \\
-50 \\
-50\end{array}$ \\
\hline
\end{tabular}

第7図 硫酸コパルト，硝酸コパルト+血清添加

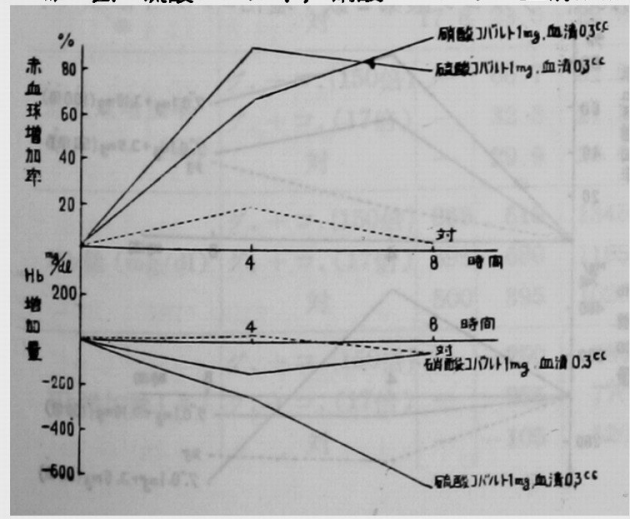

間で硫コ.90\%，硝コ.67.2\%，8時間で硫コ.80\%，硝コ． 95.19となり，之に対し対照の増加率は夫ょ19.4\%， 3.3\%に過ぎない，即ち対照との差が硫コ.では 4 時 間70.6\%，8時間76.7\%, 硝コ.では 4時間47.8\%, 8 時間では91.79となり著しい差異を示す. 之を更 に単独添加の場合に比すると 4 時間での堌加率の対 照との差硫コ.25.5\%,硝コ.17.29及び 8 時間での差 硫コ.37.4\%，硝コ.14\%に比して明かに血清添加の場 合が强い増血作用をあらわす。 之に対し $\mathrm{Hb}$ 量の 方は硫コ., 硝コ.共に対照よりかなり增加が悪く，4, 8 時間共に培羡前よりも減少し殊に硫コ.は 4 時間で $240 \mathrm{mg}$, 8時間で $650 \mathrm{mg}$ の減少を示す. 対照は殆ん ど各時間共增減をみない. 而して単独添加の際には 両者共に明かな対照との差はなく，4 時間で対照と の差硫コ.10 mg, 硝コ. $35 \mathrm{mg}, 8$ 時間では夫ぬ $15 \mathrm{mg}$ 及び $40 \mathrm{mg}$ で，両者共培羡前の価より甚しい减少 は見られない，即ちこの際血清の添加は Hb 生成 に対し悪影辢を与える.

以上コバルト類と血清の合併添加を要約すると, 単独添加で増血効果の悪かつた塩化コバルトでは血 清の添加は赤血球, $\mathrm{Hb}$ 何れの增加にも好影響を与 えないか，硝酸コバルト，硫酸コハルルでは単独添 加で見られた低色性の增血効果を助長するように思 われる。

\section{第 5 章 鉄刘とコハイルトと同時添加}

第 1 編に於て試みた諸種鉄剂の中, 最子 $\mathrm{Hb}$ 增 兽を来さしめたクルコン酸第 2 鉄と第 3 章に述べた 各種コバルト塩類とを同時に添加しその効果を検し た. 先つ最も増血効果の悪かつた塩化コハルト（以 下塭コ.)を用い, 鉄郕との量比を種々に変えて添加 してみた.

第1節 クルコン酸第 2 鉄, 塭化コパルト

添加（第 8 表, 第 8 図)

先づグ. $1 \mathrm{mg}$ に対し塩コ. $50 \mathrm{mg}$ ，即ちグ. : コ.を50 倍の比に加えてみるに赤血球增加率は第 8 表の如く 4, 8 時間共に対照より悪い. 又 $\mathrm{Hb}$ 量も時間と共 に減少の一途を辿り，4 時間に於ては対照より少し く減少の度が小であるが，8時間では甚しく減少し 対照よりる $400 \mathrm{mg}$ 以上減る. 第 1 編に述へた如く， $ク$. $1 \mathrm{mg}$ 単独添加では赤血球は対照に比し増加率が かなり大きく，又 $\mathrm{Hb}$ 晅も僅かに対照より増えて いるに拘えらず,コパル添加を行うとかかる堌血 障害を起すのはコバルトの添加星が多すきるのでは ないかと思い，次にク $.0 .4 \mathrm{mg}$ とコ. $20 \mathrm{mg}$ とを同 
第 8 寻 クルコン酸第 2 鉄+塭化 コハルト添加 (1)

ク.ニクルコン酸第 2 鉄

\begin{tabular}{|c|c|c|c|c|}
\hline & & 培苳前 & 4 時間 & 8 時間 \\
\hline \multirow{2}{*}{ 赤血球数 (104) } & グ.+コ.(50倍) & 13.1 & 16.6 & $\mid 16.9$ \\
\hline & 対 & 10.2 & 14.8 & 16.6 \\
\hline \multirow{2}{*}{$\begin{array}{r}\text { 赤血球增加率 } \\
\text { (\%) }\end{array}$} & グ.+コ.(50倍) & - & 26.7 & 29.0 \\
\hline & 対 & - & 45.0 & 62.1 \\
\hline \multirow{2}{*}{$\mathrm{Hb}(\mathrm{mg} / \mathrm{dl})$} & グ.+コ.(50倍) & 1010 & 615 & 40 \\
\hline & 対 & 865 & 395 & 345 \\
\hline \multirow[t]{2}{*}{$\mathrm{Hb}$ 增加 ("I) } & グ.+コ.(50倍) & - & -395 & -970 \\
\hline & 対 & - & $|-470|$ & -520 \\
\hline
\end{tabular}

第 8 図 クルコン酸第 2 鉄+塩化コハルト卜添加 (1)

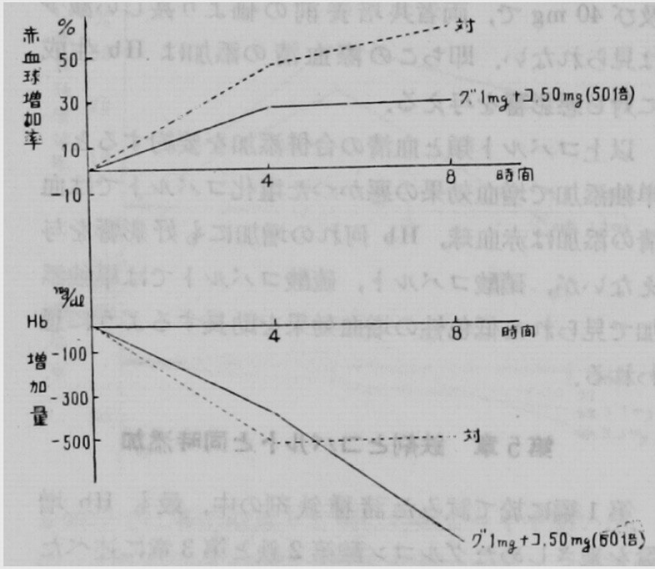

時飞添加してみた（第 9 表，第 9 四)，表の如く先 づ赤血球增加率は 4 時間で7.7\%，8時間で3.6\%対 照より大となり, 又 Hb 疍は4 時間ではほほ対照 と同じ增加を示すが，8時間に至るや対照は $30 \mathrm{mg}$

第 9 表 クルコン酸第 2 鉄+塩化 コハルト添加 (2)

\begin{tabular}{|c|c|c|c|c|}
\hline & & 培養前 & 4 時間 & 8 時間 \\
\hline \multirow{2}{*}{ 赤血球数 (104) } & ク.+コ.(50倍) & 8.9 & 12.0 & 11.3 \\
\hline & 対 & 14.4 & 18.3 & 17.5 \\
\hline \multirow{2}{*}{$\begin{array}{l}\text { 赤血球增加率 } \\
\text { (\%) }\end{array}$} & グ.+コ.(50倍) & - & 34.8 & 27.0 \\
\hline & 対 & - & 27.1 & 23.4 \\
\hline \multirow{2}{*}{$\mathrm{Hb}$ 量 $(\mathrm{mg} / \mathrm{dl})$} & タூ.+コ.(50倍) & 375 & 600 & 1100 \\
\hline & 対 & 190 & 445 & 220 \\
\hline \multirow{2}{*}{ Hb增加量 (" ) } & タ.+コ.(50倍) & - & 225 & 725 \\
\hline & 対 & - & 255 & 30 \\
\hline
\end{tabular}

第 9 困 クルコン酸第 2 鉄+塭化コハルト添加 (2)

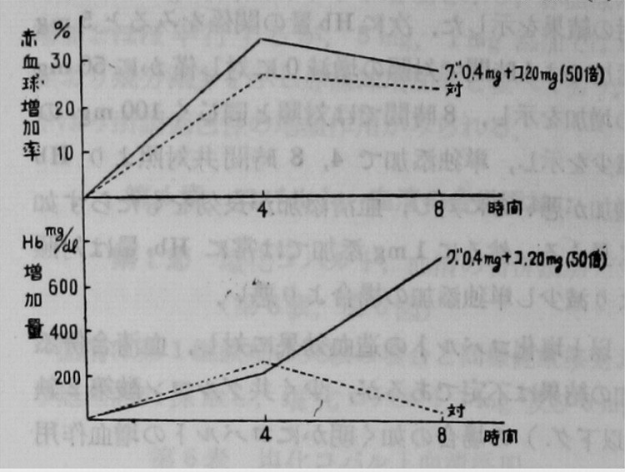

に減少するに対し添加例は $725 \mathrm{mg}$ と甚しい増加を 示した。

次に更にク.の量を $0.1 \mathrm{mg} に$ 減らすと共にコ.の量も $5 \mathrm{mg}$ に減じク. .コ.の比はやはり50倍にして添加す るに (第10表, 第10図)，対照の赤血球增加率は 4

第10表 クルコン酸第 2 鉄+塩化 コパト添加 (3)

\begin{tabular}{|c|c|c|c|c|}
\hline & & 培爰前 & 4 時間 & 8 時間 \\
\hline \multirow{3}{*}{ 赤血球数 $\left(10^{4}\right)$} & $y+z .(50$ 倍) & 9.1 & 14.1 & 12.5 \\
\hline & タ.+コ.(100倍) & 8.4 & 15.5 & 13.7 \\
\hline & 対 & 11.0 & 12.8 & 14.9 \\
\hline \multirow{3}{*}{$\begin{array}{r}\text { 赤血球增加率 } \\
\text { (\%) }\end{array}$} & ク.+コ.(50倍) & - & 55.7 & 38.0 \\
\hline & タ.+コ (100倍) & - & 83.3 & 62.0 \\
\hline & 対 & - & 17.0 & 35.5 \\
\hline \multirow{3}{*}{$\mathrm{Hb}$ ( $(\mathrm{mg} / \mathrm{dl})$} & グ. コ.(50倍) & 500 & 980 & 110 \\
\hline & ク.+ ב.(100倍) & 190 & 100 & 100 \\
\hline & 対 & 420 & 120 & 150 \\
\hline \multirow{3}{*}{$\mathrm{Hb}$ 增加 量 } & グ+コ.(50倍) & - & 480 & -390 \\
\hline & グ.コ.(100倍) & - & -90 & -90 \\
\hline & 対 & - & -300 & -270 \\
\hline
\end{tabular}

第10図 グルコン酸第 2 鉄+塩化コパルト添加 (3)

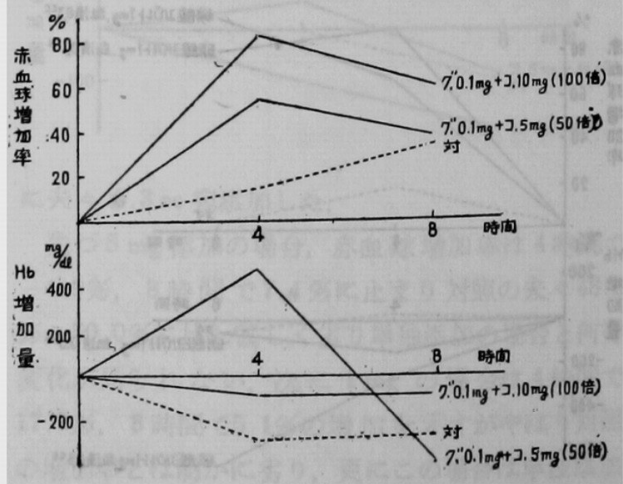


時間17.0\%k過ぎないのと対し，55.7\%と甚しく增 加し8時間ては之より减少して大体対照と等しくな 3.

次K Hb は対照が 4 時間で培前飞比して $300 \mathrm{mg}$ 声少を示すに対し， $480 \mathrm{mg}$ の增加をる，

著明な差を示す。 8 時間では之より急做に隇少し， 対照よりるやや少なくなる．以上の如く鉄の添加実 梌伦於てク.0.1 mg 単独添加ては著明な赤血球の増 加る Hb の增量も見られず，又塩コ. $5 \mathrm{mg}$ の単独添 加てる却つて(一)の增血劣果をみるのと対し，上記 の如くク・イ適当量のコ、を同時に添加するとはじめ て赫球数殊飞 Hb 量の明かな堌加が見られた.か

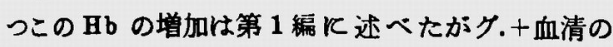
察の Hb 増加星, 例えばク. $0.6 \mathrm{mg}$ K血清 $0.5 \mathrm{cc}$ 添加した場合の $205 \mathrm{mg}$ と比較して更に大きく，従 ってコハルルトタ.のHb構成を皘極的に支持する ことが推量される。

次イク. $0.1 \mathrm{mg}$ 飞対し垣コ. $10 \mathrm{mg}$ ，即ちグ.コ.= $1: 100$ の比飞添加してみた (第10表, 第10罒). 赤 血球增加率は対照の 4 時間17\%，8時間35.5\%対 し, 夫^83.3\%及び63\%と大きい差をみるが，Hb 量は対照の 4 時間 $300 \mathrm{mg}$ 減, 8 時間 $270 \mathrm{mg}$ 澸飞比 し夫ネ $90 \mathrm{mg}$ 減で，即ち対照よりやや減少率が低い，

更にコバルトの量を增しク.: コ.=1 150 の比に すると(第11表, 第11四)，赤血球增加率は中はり大き 〈対照を引き離し，4時間で6.8\%，8時間て554.5 \%の差をるる. 然るに Hb の増加星は却つて対照 より劣り４時間で $145 \mathrm{mg}, 8$ 時間で $40 \mathrm{mg}$ の差

第11表 クルコン酸第 2 鉄+塩化 コハルト添加 (4)

\begin{tabular}{|c|c|c|c|c|}
\hline & & $\begin{array}{l}\text { 培贾 } \\
\text { 前 }\end{array}$ & 4 時間 & 8 時間 \\
\hline \multirow{3}{*}{ 赤血球数 (104) } & グ. +コ.(150倍) & 7.0 & 11.8 & 12.8 \\
\hline & ク. + コ.(17倍) & 16.0 & 21.1 & 19.4 \\
\hline & 対 & 17.8 & 23.0 & 22.8 \\
\hline \multirow{3}{*}{$\begin{array}{r}\text { 赤血球増加率 } \\
(\mathscr{6})\end{array}$} & グ.+コ.(150倍) & - & 66.7 & 82.5 \\
\hline & グ.+コ.(17倍) & - & 32.3 & 21.5 \\
\hline & 対 & - & 29.9 & 28.0 \\
\hline \multirow{3}{*}{ Hb } & ク.+コ.(150倍) & 865 & 615 & 1345 \\
\hline & グ.+コ.(17倍) & 395 & 680 & 1165 \\
\hline & 対 & 500 & 395 & 1020 \\
\hline \multirow{3}{*}{ 耳b增加量 (" ) ) } & $\mid$ クூ. +コ.(150倍) & - & -250 & 480 \\
\hline & グ. +コ.(17倍) & - & 285 & 770 \\
\hline & 対 & - & -105 & 520 \\
\hline
\end{tabular}

第11図 クルコン酸第 2 鉄+笽化コパルト添加 (4)

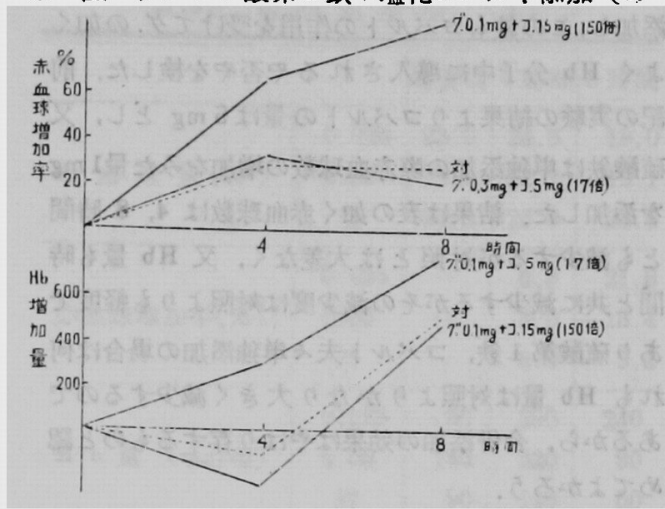

を認める. 更に次には反対にコ.の最を減らして $5 \mathrm{mg}$ とし，グの量は $0.3 \mathrm{mg}$ としグ. コ.=1:17 の比にして添加すると(第11表，第11罒)，赤血球增 加率は各時間共対照と殆んど差をみないが， Hb 量 は 4 時間で $285 \mathrm{mg}, 8$ 時間で $770 \mathrm{mg}$ の増加を示 し，対照との差は夫ん $390 \mathrm{mg}$ 及び $250 \mathrm{mg}$ であり， 既述の如く，添加するコ.の量が多いと堌血効果は障 害されるようである。

第 2 箇 硫酸第 1 鉄, 塩化コバルトの添加 （第12表，第12図）

前編に於て無機の 2 価鉄として添加したが最も増

第12表 硫酸第 1 鉄+塭化コハルト添加

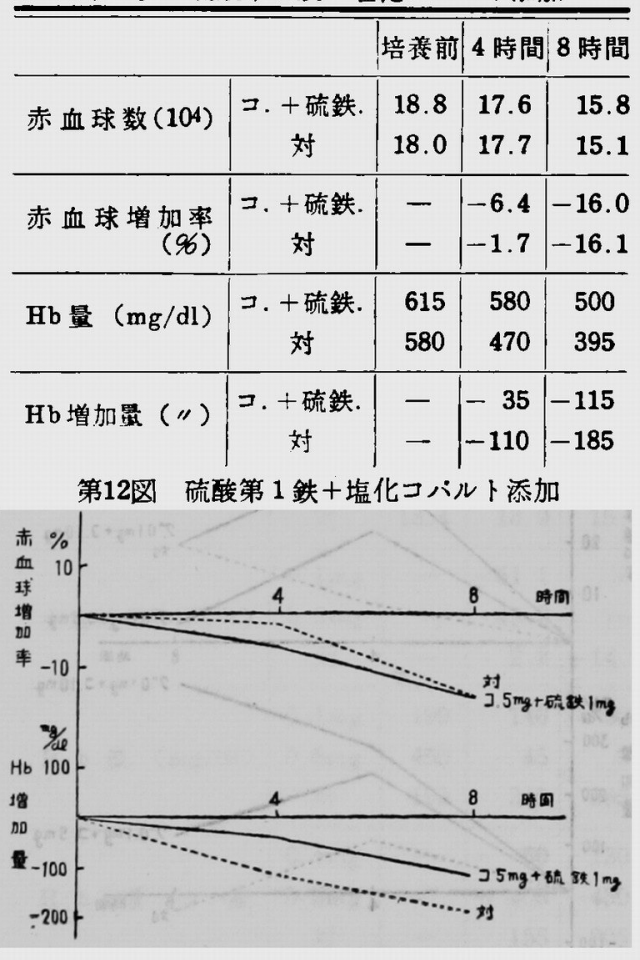


血効果の悪かつた硫酸第 1 鉄と塩化コバルトを合併 添加し、この鉄もコバルトの作用を受けてク．の如く よく Hb 分子中に導入されるや否やを検した，前 記の実験の結果よりコバルトの晨は $5 \mathrm{mg} と し$, 又 硫酸鉄は単独添加の際赤血球数の増加をみた最 $1 \mathrm{mg}$ を添加した. 結果は表の如く赤血球数は 4,8 時間 とる減少するが対照とは大差なく, 又 Hb 量包時 間と共に減少するかその減少度は対照上りる軽度て あり硫酸第 1 鉄, コバルト夫な单独添加の場合仕何 れる Hb 量は対照よりかなり大きく減少するので あるから，合併添加の效果はやはり存するるのと認 めてょかろう。

整 3 第 グルコン第 2 鉄, 硫酸コバルトの 喬加（第13表，第13図）

$ク$ ク. $0.1 \mathrm{mg}$ K対し硫コ. $5 \mathrm{mg}$ 及び $10 \mathrm{mg}$ を，即ち 両者の比を50倍及び 100 倍にして合併添加した。先

第13表 ゲルコン酸第 2 鉄+硫酸コパルト忝加

\begin{tabular}{|c|c|c|c|c|}
\hline & & 培善前 & 4 時間 & 8 時間 \\
\hline \multirow{3}{*}{ 赤血球数 (104) } & $\not ु .+=.5 \mathrm{mg}$ & 33.1 & 40.6 & 34.2 \\
\hline & $\mathscr{H}++コ .10 \mathrm{mg}$ & 26.3 & 35.6 & 31.4 \\
\hline & 対 & 31.9 & 34.4 & 38.1 \\
\hline \multirow{3}{*}{$\begin{array}{r}\text { 赤血球增加率 } \\
(96)\end{array}$} & グ.t ב.5 mg & - & 22.6 & 3.3 \\
\hline & $\not h .+=.10 \mathrm{mg}$ & - & 35.3 & 19.8 \\
\hline & 対 & - & 7.8 & 19.4 \\
\hline \multirow{3}{*}{$\mathrm{Hb}$ 量 (mg/dl) } & $\not ூ .+=.5 \mathrm{mg}$ & 500 & 740 & 615 \\
\hline & $\not g .+=.10 \mathrm{mg}$ & 450 & 740 & 865 \\
\hline & 対 & 500 & 605 & 460 \\
\hline \multirow{3}{*}{$\mathrm{Hb}$ 增 加 量 } & $\mathscr{H}++\beth .5 \mathrm{mg}$ & 一 & 240 & 115 \\
\hline & $\not ク .+=.10 \mathrm{mg}$ & - & 290 & 415 \\
\hline & 対 & - & 105 & -40 \\
\hline
\end{tabular}

第13図 クルコン酸第 2 鉄+硫酸コパルト添加

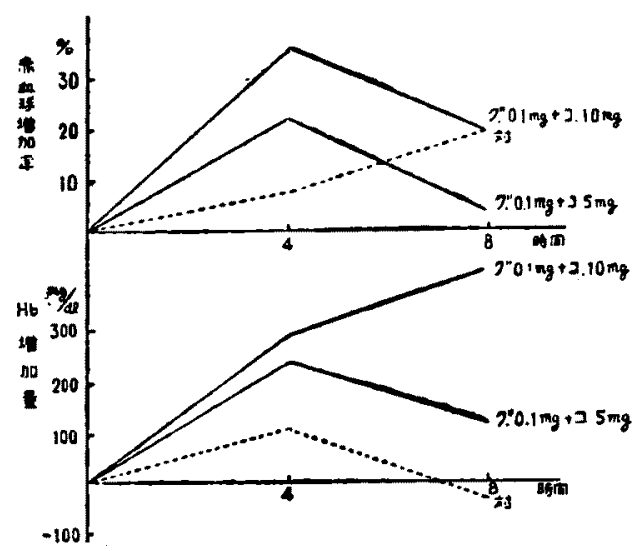

ぷ. $5 \mathrm{mg}$ の場合は赤血球増加率は 4 時間で対照 より約15\%大きいか，8時間では逆に16名小となる。 $\mathrm{Hb}$ 量は之に対し各時間に於てよく增加し，対照よ り $140 \mathrm{mg}$ 内外の増量を示士. 次に $=10 \mathrm{mg}$ の場合 では赤血球増加东は前者の場合より多くなり，4時 間で対照との差27.5\%，8時間ては浪ほ対照と等し くなる，Hb 骨るまた著明に增加し，4時間で対照 よりる $185 \mathrm{mg}$ 增加，8時間では刘照が $40 \mathrm{mg}$ 減と なるに対し $415 \mathrm{mg}$ の増加を示す. 即ちグ.と硫コ.の 合併添加ではコ.を100倍の比に鉄と合併した場合が 増血効果がよく，赤血球增加率は単独添加或は第 1 編に述ベたグ.と血清の合併添加の場合に比し大苃な いが， Hb は単独添加の場合何れの添加嘼てす著明 に減少するにる拘わらずこの場合には著明な増加を 示した。 又このHb 增加量はグ.十塩コ。を $1: 50$ の 比に加えた場合の最大增加量より少り，グ血清の 場合のそれよりもかなり大きい值を示した。

\section{第 4 第 グルコン酸第 2 鉄，硝酸コバルト の添加（第14表，第14図）}

同じくグ.0.1 mgk対し硝コ.を $5 \mathrm{mg}$ 及び $10 \mathrm{mg}$ 添加した. 赤血球增加は $5 \mathrm{mg}$ て著しく，4時間で 75\%の增加乎を示し, 対照屰飞2.9 名の減少を示 す. 8 時間で急激炕減少するが，な拉対照よりは よく，単独添加の場合，各時間とも対照よりやや増 加率が悪かつたのに比し明かに合併添加の効果が認 められた. $10 \mathrm{mg}$ の場合は各時間共対照より大であ るか： $5 \mathrm{mg}$ の場合ほどの大差はなく，又単独添加の 際と此較してb殆んど差をみない，次に Hb 量に ついて述べると $5 \mathrm{mg}$ 合併添加では単独添加の際 4

$$
\text { 第14表 クルコン酸第 } 2 \text { 鉄+硝䣼コバルト添加 }
$$

\begin{tabular}{|c|c|c|c|c|}
\hline & & 培盖前 & 4 時間 & 8 時間 \\
\hline 赤血球数 (104) & $\left|\begin{array}{c}\mathscr{.}+コ .5 \mathrm{mg} \\
\not ூ .+\beth .10 \mathrm{mg} \\
\text { 奶 }\end{array}\right|$ & $\begin{array}{l}11.2 \\
13.5 \\
13.8\end{array}$ & $\begin{array}{l}19.6 \\
15.0 \\
13.4\end{array}$ & $\begin{array}{l}11.8 \\
12.1 \\
11.0\end{array}$ \\
\hline $\begin{array}{r}\text { 赤血球増加率 } \\
(96)\end{array}$ & $\left|\begin{array}{c}\mathscr{.}+=.5 \mathrm{mg} \\
\mathscr{H} .+=.10 \mathrm{mg} \\
\text { 对 }\end{array}\right|$ & $\begin{array}{l}- \\
-\end{array}$ & $\left|\begin{array}{r}75.0 \\
11.1 \\
-2.9\end{array}\right|$ & $\begin{array}{r}5.4 \\
-10.4 \\
-20.3 \\
\end{array}$ \\
\hline $\mathrm{Hb}$ 量 (mg/dl) & $\mid \begin{array}{c}\mathscr{.}+=.5 \mathrm{mg} \\
\mathscr{H}++=.10 \mathrm{mg} \\
\text { 对 }\end{array}$ & $\begin{array}{l}215 \\
300 \\
310\end{array}$ & $\begin{array}{l}320 \\
460 \\
265\end{array}$ & $\begin{array}{l}245 \\
220 \\
220\end{array}$ \\
\hline Hb増加量 (") & $\begin{array}{c}\not ூ .+コ .5 \mathrm{mg} \\
\mathscr{H}+\neg .10 \mathrm{mg} \\
\text { 对 }\end{array}$ & $\begin{array}{l}- \\
-\end{array}$ & $\begin{array}{r}105 \\
160 \\
-45\end{array} \mid$ & $\begin{array}{r}30 \\
-80 \\
-90\end{array}$ \\
\hline
\end{tabular}


第14区 クルコン酸第 2 鉄+硝酸コバルト添加

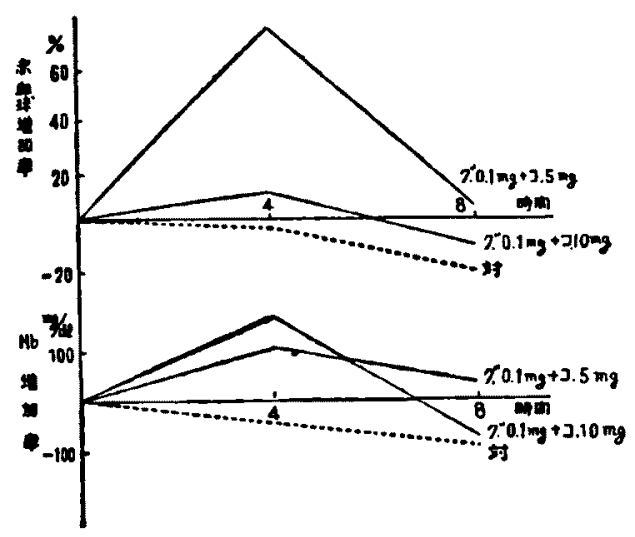

時間て対照より $60 \mathrm{mg}$ 増加の少なかつたのに対し $150 \mathrm{mg}$ 增加が大となり，8時間です単独添加の場 合対照より $30 \mathrm{mg}$ 減少度が小であつたのK対し今 度恃対照の-90 mg K対して+30 mgであるので, 踏局対照より $120 \mathrm{mg}$ の増加を示した. 又 $10 \mathrm{mg}$ 合件添加した場合にはその增加量は 4 時間で対照の 增加量より $205 \mathrm{mg}$ 大であり，硝コ $10 \mathrm{mg}$ 単独添加 の察の增加量が対照より $60 \mathrm{mg}$ 大であつたのに比し すくれた动果を示す. 即ち硝酸コバルトもまたク・と 合錭した場合かなり著しい增血効果の增大を示し、 特飞 Hb 量の增大は $10 \mathrm{mg}$ 合併の場合, 即ちク. : コ.を1: 100 の比に加えた場合がきつている. し かしこの增加量俚グ：塩コ.を $1: 50$ の割合飞加え た場合よりは劣る。

\section{第6 咅釾の增血作用}

第1箅 硫酸銅添加（第15表，第15図，第 16表)

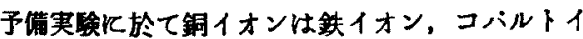
オンよりかなり金属毒性が强いことが分かつたので 添量を憾， $0.025 \mathrm{mg}$ 及び $0.05 \mathrm{mg}$ とした，と の場合も赤血球增加率仕対照上り $2 \sim 5 \%$ 前後悪い 加， Hb 增加量恃対照上り大きく，殊火 $0.025 \mathrm{mg}$ 添加で 8 時間で $190 \mathrm{mg}$ の差をみた。 $0.05 \mathrm{mg} て ゙$ 64時間で対照比し $130 \mathrm{mg}$ 增加大となり，お まり著明とはいえないが銅の Hb 構成促進作用が 諰められる。次試み飞添加量を多くして0.1 mg 及び $0.5 \mathrm{mg}$ とすると第 16 表の如く何れる著明《赤

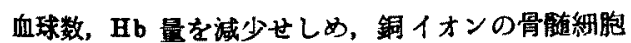
に対する毒性の强いことを示す。
第15表 硫酸銅添加 (1)

\begin{tabular}{|c|c|c|c|c|}
\hline & & 培眚前| & 4 㭙間 & 8 時問 \\
\hline \multirow{3}{*}{ 赤血球数 (104) } & 0.025 & 23.0 & 24.5 & 18.0 \\
\hline & 0.05 & 23.4 & 22.7 & 19.1 \\
\hline & 対 & 24.8 & 26.9 & 23.5 \\
\hline \multirow{3}{*}{ 赤血球增加率(\%) } & 0.025 & - & 6.8 & -21.8 \\
\hline & 0.05 & - & 3.0 & -18.4 \\
\hline & 対 & - & 8.9 & -5.3 \\
\hline \multirow{3}{*}{$\mathrm{H} \mathrm{b}$ 量 $(\mathrm{mg} / \mathrm{dl})$} & 0.025 & 90 & 290 & 240 \\
\hline & 0.05 & 140 & 320 & 90 \\
\hline & 对 & 90 & 140 & 50 \\
\hline \multirow{3}{*}{$\mathrm{Hb}$ 增加量 (") } & 0.025 & - & 200 & 150 \\
\hline & 0.05 & - & 180 & -50 \\
\hline & 对 & - & 50 & -40 \\
\hline
\end{tabular}

第15四 硫酸銅添加 (1)

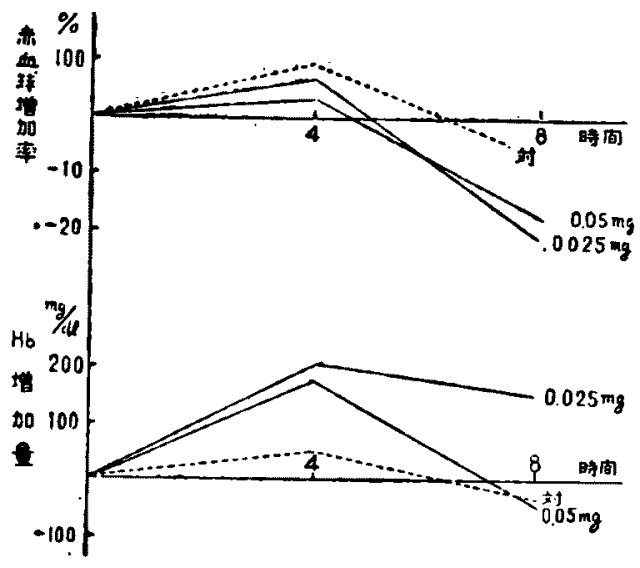

第16表 硫酸銅添加 (2)

\begin{tabular}{|c|c|c|c|c|}
\hline & & |培倳前| & 4 時間 & 8 時間 \\
\hline \multirow{3}{*}{ 赤血球 数 (104) } & $0.1 \mathrm{mg}$ & 17.5 & 6.8 & - \\
\hline & $0.5 \mathrm{mg}$ & 13.8 & 4.0 & - \\
\hline & 対 & 18.4 & 18. 9 & 15.7 \\
\hline \multirow{3}{*}{ 赤血球增加率(\%) } & $0.1 \mathrm{mg}$ & - & -61.1 & - \\
\hline & $0.5 \mathrm{mg}$ & - & -49.2 & - \\
\hline & 対 & - & 2.2 & -14.7 \\
\hline \multirow{3}{*}{ H b 量 $(\mathrm{mg} / \mathrm{dl})$} & $0.1 \mathrm{mg}$ & 190 & 140 & 60 \\
\hline & $0.5 \mathrm{mg}$ & 450 & 45 & 0 \\
\hline & 対 & 190 & 345 & 395 \\
\hline \multirow{3}{*}{ H b 增 加显 } & $0.1 \mathrm{mg}$ & - & -50 & -130 \\
\hline & $0.5 \mathrm{mg}$ & - & -405 & -450 \\
\hline & 対 & - & 155 & 205 \\
\hline
\end{tabular}


基 2 场 塩化銅添加（第17表，第17园，第 18表)

同じく添加昷は $0.025 \mathrm{mg}$ 及び $0.05 \mathrm{mg}$ とした。 共に赤血球增加率は悪く，殊飞 $0.05 \mathrm{mg}$ では 8 時 間で测定不能となつた。 Hb 聂は $0.025 \mathrm{mg}$ 添加で 4 時間及び 8 時間に於て対照より夫↔ $225 \mathrm{mg}$ 及び $295 \mathrm{mg}$ 增加大となるが，0.05 mg 添加では逆に対 照より少し悪くなる，0.1及び $0.2 \mathrm{mg}$ の大量を添 加すると硫酸銅の場合と同じく著明な障害作用を認 め赫球， $\mathrm{Hb}$ 共䘠娍する，以上塭化銅は硫酸銅よ りやや金属毒性が強いが，なお少量を添加すればHb 增成作用をあらわす。

第17表 塩化銅添加 (1)

\begin{tabular}{|c|c|c|c|c|}
\hline & & 培奏前 & 4 時間 & 8 時間 \\
\hline \multirow{3}{*}{ 赤血球 数 (104) } & 0.025 & 13.0 & 12.0 & 9.6 \\
\hline & 0.05 & 12.0 & 8.0 & 一 \\
\hline & 対 & 16.3 & 14.1 & 5.7 \\
\hline \multirow{3}{*}{ 赤血球增加率(官) } & 0.025 & - & -7.8 & -26.1 \\
\hline & 0.05 & - & 33.0 & - \\
\hline & 対 & - & -13.5 & -65.0 \\
\hline \multirow{3}{*}{$\mathrm{H} b$ 量 $(\mathrm{mg} / \mathrm{dl})$} & 0.025 & 290 & 615 & 395 \\
\hline & 0.05 & 290 & 290 & 0 \\
\hline & 対 & 190 & 290 & 0 \\
\hline \multirow{3}{*}{ Hb 增加量 ( " ) } & 0.025 & - & 325 & 105 \\
\hline & 0.05 & - & 0 & -290 \\
\hline & 対 & - & 100 & -190 \\
\hline
\end{tabular}

第17四嚓化銅添加（1）

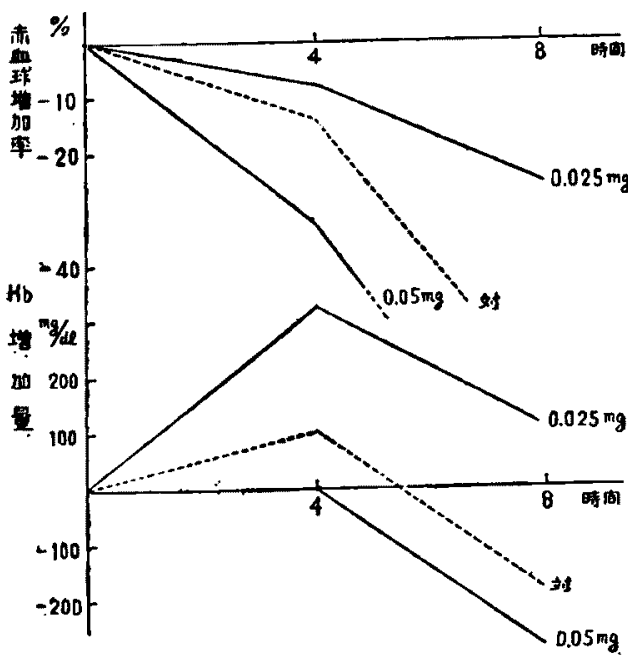

第18表 塩化銅添加

(2)

\begin{tabular}{|c|c|c|c|c|}
\hline & & 培秋前 & 4 時間 & ' 8 時間 \\
\hline \multirow{3}{*}{ 赤血 球 数 (104) } & $0.1 \mathrm{mg}$ & 27.7 & 5.6 & - \\
\hline & $0.2 \mathrm{mg}$ & 25.6 & 4.9 & - \\
\hline & 奶 & 27.9 & 30.5 & 29.7 \\
\hline \multirow{3}{*}{ 赤血球增加事( } & $0.1 \mathrm{mg}$ & - & -76.9 & - \\
\hline & $0.2 \mathrm{mg}$ & - & -80.9 & - \\
\hline & 対 & - & 9.3 & 6.1 \\
\hline \multirow{3}{*}{$\mathrm{H} b \pm(\mathrm{mg} / \mathrm{dl})$} & $0.1 \mathrm{mg}$ & 395 & 190 & 0 \\
\hline & $0.2 \mathrm{mg}$ & 415 & 490 & 14.5 \\
\hline & 対 & 450 & 500 & 395 \\
\hline \multirow{3}{*}{ H b 增 加 量 } & $0.1 \mathrm{mg}$ & - & -200 & -395 \\
\hline & $0.2 \mathrm{mg}$ & - & 75 & -270 \\
\hline & 対 & $\longrightarrow$ & 50 & -55 \\
\hline
\end{tabular}

第 3 節 硫酸銅，盐化銅と血清の合併添加 （第19表，第19図）

両者共住 $0.025 \mathrm{mg}$ を血清 $0.3 \mathrm{cc}$ と併せて添加し

第19表 塩化銅，硫酸銅＋血清添加

\begin{tabular}{|c|c|c|c|c|}
\hline & & 培美前 & 4 時間 & 8 時間 \\
\hline \multirow{3}{*}{ 赤血球数 (104) } & 塭銅，血. & 11.9 & 9.7 & 8.9 \\
\hline & 硫銅，血. & 9.0 & 7.0 & 7.2 \\
\hline & 対 & 15.8 & 17.0 & 14.9 \\
\hline \multirow{3}{*}{ 赤血球增加夷(\%) } & 塩銅，血. & 一 & -18.5 & -25.2 \\
\hline & 硫銅，血. & - & -22.2 & -20.0 \\
\hline & 対 & - & 7.6 & -5.8 \\
\hline \multirow{3}{*}{ A b $(\mathrm{mg} / \mathrm{dl})$} & 塩銅, 血. & 110 & 190 & 240 \\
\hline & 硫銅，血. & 190 & 290 & 190 \\
\hline & 対 & 190 & 240 & 240 \\
\hline \multirow{3}{*}{ H b 增 加 } & 塭銅, 血. & 一 & 80 & 130 \\
\hline & 硫銅，血. & 一 & 100 & 0 \\
\hline & 对 & - & 50 & 50 \\
\hline
\end{tabular}

第19図 塭化銅，硫酸銅＋血清添加

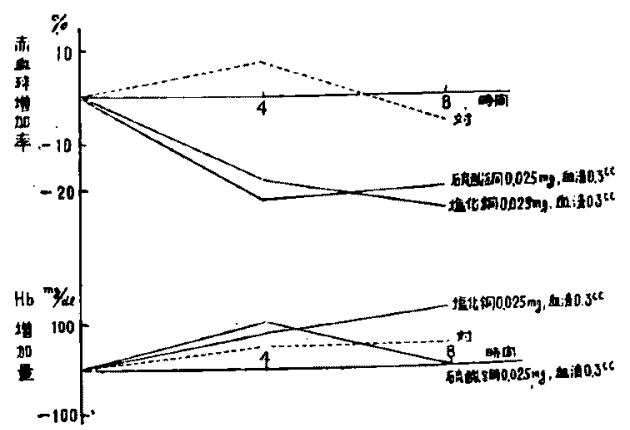




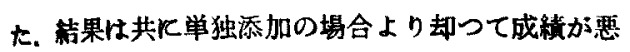

く, 赤血球增加事は各時間共15〜30\%対照より悪い。 Hb 国は 4,8 時間何れ6対照と大差をみない，即 ち鉄の場合と異り血清の添加は增血作用に好影霸を。 与えない.

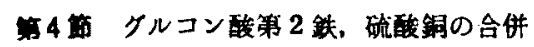
添加（第20表、第20园）

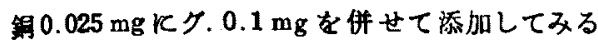
K、赫球数は時間と共に減少するがその減少度は 対照より僅か下大であり，又 $\mathrm{Hb} 4$ 時間で対照 が $20 \mathrm{mg}$ の城少を示すに対し $200 \mathrm{mg}$ の增加をみ, 単独添加の祭の增加率の差 $150 \mathrm{mg}$ より少し大きい 考を示才、既述の如く詮イカンは金属毒性が强く更 にキの上に鉄イオンを加えたのであるから亦血球数 は減少したが、なお Hbは単独添加の際よりよく 增量した。

第20表 硫酸銅十グルコン酸第 2 鉄添加

\begin{tabular}{|c|c|c|c|c|}
\hline & & 培羡前 & 4 時間 & 8 時間 \\
\hline \multirow{2}{*}{ 赤盘球数 (104) } & 銅, グ. & 14.1 & 11.3 & 11.3 \\
\hline & 対 & 17.5 & 13.9 & 13.5 \\
\hline \multirow{2}{*}{ 赤血球增加率( } & 銅, ク. & - & -20.0 & -20.0 \\
\hline & 対 & - & -20.1 & -22.8 \\
\hline \multirow{2}{*}{ H b 量 $(\mathbf{m g} / \mathrm{dl})$} & 銅, グ. & 140 & 340 & 110 \\
\hline & 対 & 140 & 120 & 90 \\
\hline \multirow{2}{*}{ Hb 增加 量 (") } & 銅, 万. & - & 200 & -30 \\
\hline & 対 & - & -20 & -50 \\
\hline
\end{tabular}

第20汹 硫酸錭+クルコン酸第 2 鉄添拟

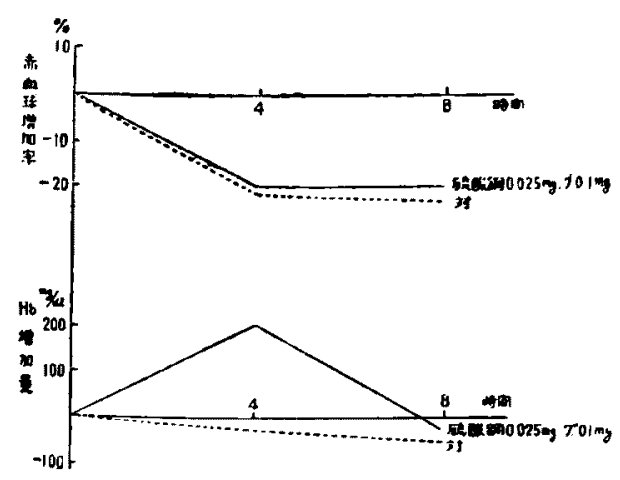

第 5 笽 グルコン酸第 2 鉄，塭化銅の合併 添加 (第21表, 第21这)

前節と同しく筍 $0.025 \mathrm{mg}$ とク $0.1 \mathrm{mg}$ を添们し

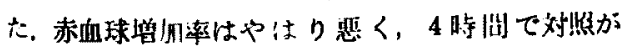

第21表 埧化銅+グルコン䣼第 2 鉄添扣

\begin{tabular}{|c|c|c|c|c|}
\hline & & 培程前 & 4 時間 & 8 時間 \\
\hline \multirow{2}{*}{ 赤血球数 (104) } & 銅, グ. & 13.8 & 11.9 & 9.8 \\
\hline & 对 & 18.4 & 19.8 & 13.3 \\
\hline \multirow{2}{*}{ 赤血球增加無(\%) } & 銅, 名。 & - & -13.8 & -28.9 \\
\hline & 对 & - & 7.6 & -27.7 \\
\hline \multirow{2}{*}{ H b 量 $(\mathbf{m g} / \mathrm{dl})$} & 銅, グ. & 240 & 605 & 160 \\
\hline & 対 & 290 & 335 & 240 \\
\hline \multirow{2}{*}{$\mathrm{Hb}$ 增加量 (") } & 銅, 7 . & - & 365 & -80 \\
\hline & 対 & - & 45 & -50 \\
\hline
\end{tabular}

第21図盍化銅+グルコン酸第 2 鉄添加

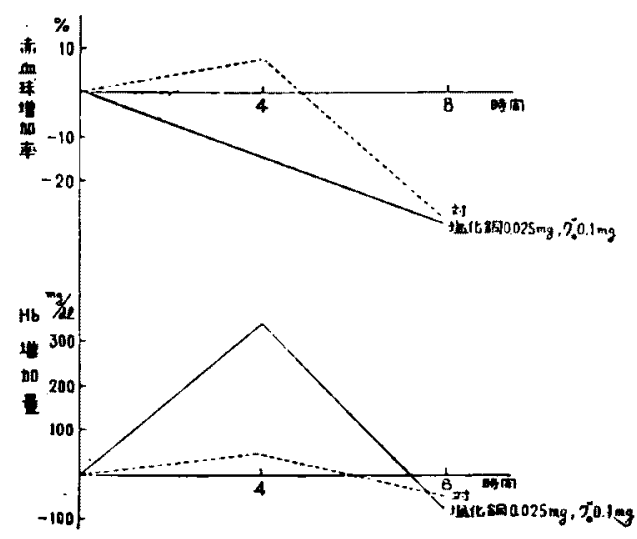

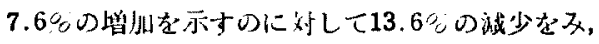

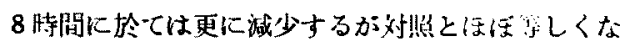

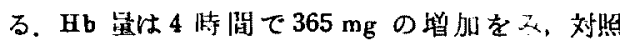
より $320 \mathrm{mg}$ 增加量が大きく, 叉単独添加の際の增 加冒の美 $225 \mathrm{mg}$ よりも大であり，硫酸銅の場合と

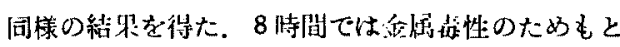

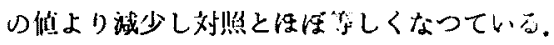

\section{第7章 鉄，銅，コバルトの3者 同時添加}

以上鉄，銅，コバルトの各をを単独或はその中の 2 者を適宜に組合わせて添加し，何れも単独添加に 優る增血効果を認めたが，ここにその3者を同時に 併世添加し， 2 者添加に更に侥る効果を得るや否や を検した(第22表，第22図)。

即ち $\mathrm{I} \cdot \not \gamma .0 .1 \mathrm{mg}$, 塭コ.5 mg, 硫酸銅（以下硫 銅.) $0.025 \mathrm{mg}$, II $ク$. $0.1 \mathrm{mg}$, 塩コ. $10 \mathrm{mg}$ ，硫銅.

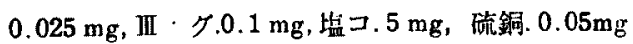

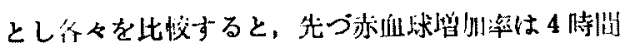


第22表 铁，コパルト，銅三者添加

\begin{tabular}{|c|c|c|c|c|}
\hline & & 培養前 & 4 時間 & 8 時間 \\
\hline \multirow{4}{*}{ 赤血球数 (104) } & I & 19.1 & 22.6 & 18.0 \\
\hline & II & 16.8 & 20.2 & 24.8 \\
\hline & III & 19.9 & 25.9 & 22.5 \\
\hline & 対 & 18.1 & 19.1 & 21.2 \\
\hline \multirow{4}{*}{$\begin{array}{r}\text { 赤血球增加率 } \\
(\%)\end{array}$} & I & - & 18.7 & -5.8 \\
\hline & II & - & 20.3 & 47.5 \\
\hline & III & - & 30.2 & 13.1 \\
\hline & 対 & -- & 5.5 & 17.1 \\
\hline \multirow{4}{*}{$\mathrm{Hb}$ 量 $(\mathrm{mg} / \mathrm{dl})$} & I & 615 & 865 & 740 \\
\hline & II & 520 & 1010 & 615 \\
\hline & III & 615 & 845 & 865 \\
\hline & 対 & 400 & 505 & 290 \\
\hline \multirow{4}{*}{ Hb 垍扣量 (") } & I & - & 250 & 125 \\
\hline & II & - & 490 & 95 \\
\hline & III & - & 230 & 250 \\
\hline & 対 & - & 105 & -110 \\
\hline
\end{tabular}

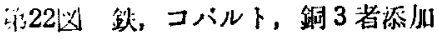

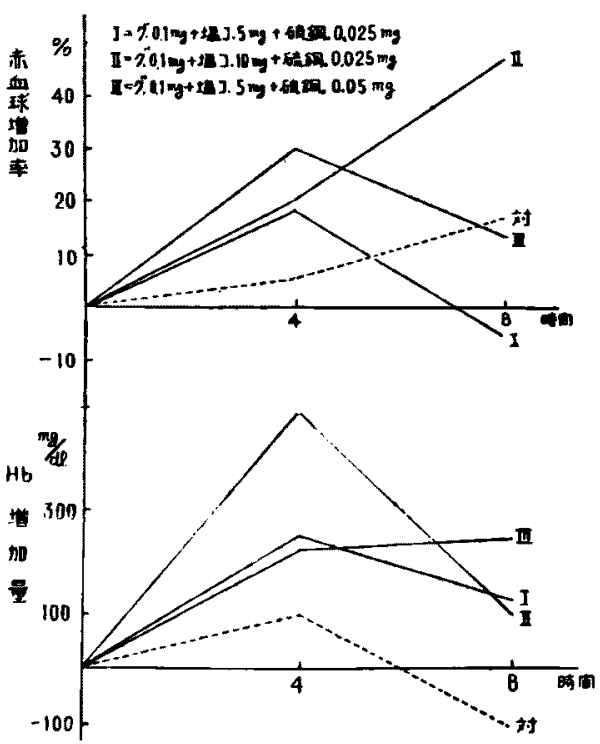

ではIIIか最も高く対照のそれより24.7\%大で，次で

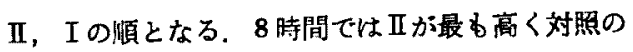
增別率を30.4\%上回り，次でII，IIの順で全体的仡

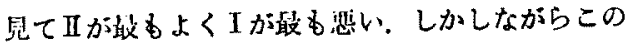

增加事住硫 照との增加率の差31.3\%，或は硫コ., 硝コ.と血清を 合伴した際の80.6\%，47.8\%，或恃グ+婥コ.(100倍) の際の66.3\%等飞比すると， 3 者同時添加は最大の

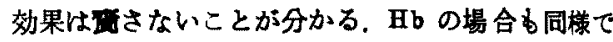
I，II，何孔。明か次対照よりよく增量寸るか， 最も著明なIIの 4 時間代於ける対照との增加量の差 は $385 \mathrm{mg}$ で,之はグ+塭コ. (50倍) の際の $780 \mathrm{mg}$

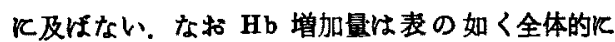
見ると而が最す大で，次でII，Iの順となる。

\section{第B章稔括及ひ考按}

1929年 Waltner Klara 及び Karl Waltner ${ }^{80)}$ け

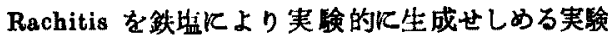
を続行中，偶然にコバルトが著明な Polyoythämie を䍂起せしめることを発見した，即ち彼等は幼弱な ラっテの食慨中にコバルトの粉末を 2 \%の割汇混し て投与するか，又仕その監類水溶液を皮下注射す ると，約 1 週間後に赤血球数及び Hb 量が20 25 タ增加することを発見した。しかしこの投与量を続 けると，その金属毒性のためラッテは約 4 週後死 亡するので，後にその量を減じ $0.5 \%$ の割に湿した が，な捄平均1050万の赤血球数增加，165\% 亿及家 Hb の增加を来したとい5. 又この增血作用はコハ ルトの投与を続ける限り動物の死至るまで持続与 るが，投与を止めれげ赤血球数も $\mathrm{Hb}$ 量む次第几 正常倬䎲復㷌するといろ，而してこのコハルトの増

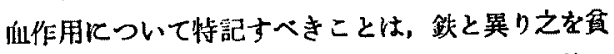
血状態陷つていない動物飞用いてもなお正常值を 遥か汇越える增血状態をあらわするとで，之は又マ ンカンルも認められ，L， Schwartzは枚マンガン鉱

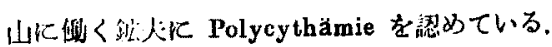

さてこのコハパけ增血作用はその後多、の学者

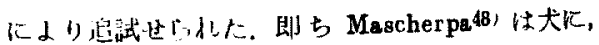
Sutter78) は二十日成，海犋及び蛙に，Kleinberg ${ }^{38)}$

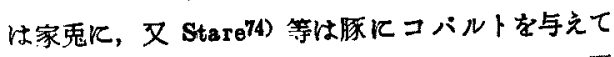
各ぬ明らかな赤血球增多症を起すことを認め大。而 してその增血機転とついてけ. Orten一派了汭) の多

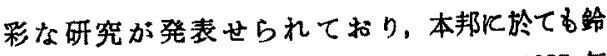
木79980)81)，安川91) 等の報告がある。即ち 1935 年 Orten はコハルトの增血作用火脾は何等主要な役割 を演しないとしこの Polycythämie はコバルト

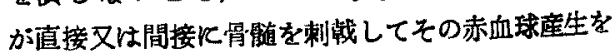
增加せしめるためであると述へてている，氏はラッテ を用い，盐化コハルトを絓口的或は皮下注的化より 
与えて赤血球数及び Hb 量の著明な增加の起る以 前们和赤血球の注目すべき增加を来すこと，又コパ ル卜（以下 Co）を注射した怔物の血清ビリルビン は対照動物のそれK比して次第飞增量してゅく等の

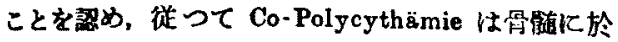
ける赫血球及び Hb 形成の增加によるもので，汽 して睡による赤血球破塿作用の洁退に起因寸る流血 中の赤血球の蓄棈によるるのでないことを知つた。 安川るまた Co-Polycythämie は甲状腺及び脾の剔 出により何等影響を受けず, 又 Co-Polycythämie を生せしめた骨髄は組織学的に赤血球形成巣の著明 な增殖が認められると述へている，又安川は網内系 填塞錫では本症は意起されないことを述へている。 さて然らばCoは如何なる作用機転で骨睢を刺 戟し赤血球形成を增加せしめるかというK，Barron 等2)仕 Ascorbin 設の投与により Co-Polycythämie の発現が障害されることを知つて，Co 滑填の呼 吸降害を起し，そのために未愁赤血球が多数に流血 中放出されるためPolycythämie を来すのである 万と述へている. Co は Mn，Fe と元秦の週期律表 上近安の位置飞あり，化学的性留上之等化類仙する こと, 又 Tsumaki85) 等に上り合成された或種のコ バ卜告類は Hb の如く上く酸素と結合すること

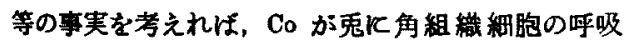
K何等かの作用を及活すことは想像灘くない。 Orten 等は效コ.を与えて Polycythemia を起した ランテの血中の Methemoglobin 是及びHb の酸素

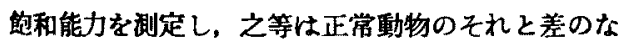
いことを知り，又 Co-Polycythemia を起した後の 血中の Co はスベクトログラム上痕䟢的飞しか認め られない等のことから，Polycythemia の機転酸 来䳢和能力の诚退した変性へモクロピンやメトーモ クロヒンの形成による general anoxemia Kよるも

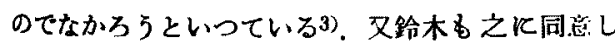
ている. 而して近時 Orten, Barron2) 等は Co 沬 S-H 基群と親和性が強く，Cobalt-cystein となり， ためК組䜌呼吸の䤃菜系連鎖が中断され組織の内部 呼吸陵害, tissue anoxia が起り, 之が骨随を刺韩 して Polycythemia を起すという. 又教室の国延43) 6 Warburg 氏梌圧装置を用いて骨䯣の呼吸解糖代 貄面の研究を行い，Co 飞組織呼吸の酻素系連銷中 断作用のあることを認めている.実際化 Co-Polycy. thämie が何等かの呼吸陵害によるるのであろうこ とは，之が高山地帯住む人々に見られる Polycythimie K䎦代していることからす想像されること
である.

さて以上の諸氏の実験は何れるCo を経口的或は 皮下注射により趿物炕投与しているが，私はその增 血作用を更飞端的飞知りたいと思い，先化前編で行 つた鉄の実験に続いて Co を単独或は鉄と共に骨部有 組織に䔖接添川した。先づ単独添加では硝コ., 硫コ. には傕か、著しい赤血球增多が見られたが，牊コ.で は逆飞対照より赤血球が減少し，胃榷火直接源加し た時塩コ.の毒性の強いことを示している，Waltner は硝コ、及び塭コ、を用いて実験しているが，㙁コ、は その毒性が强く，Polycythämin 惹起作用が時化不定 であると述へている86). 而して私の実験てはHb 鿉 は却つて培羡前より減少することが多く，諸家の如 く少くとも著しい Hb の增量を見ない，勿論諸家

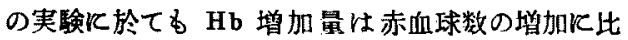

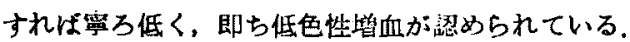
この実験では骨隺紏胞は培養前に Gey 氏液で数回 洗湅され，従つて血清鉄は供給されない状態江置か れているのであるから，Coの作用てより耳細胞よ りの赤血球生成のみが刺戟され，Hb 生成が之に及 ばないことは当然考えられる。しかしながら次に血 清を同時添游しても增血作用飞好結果を及ぼさな かつたのであり，この原因はな和今後の追求に侯た ね㤌ならないが，恐らく血清の添加量炕問题があっ たのではなかららかとる考光られる。

さて以上の事赛から Co と共㶤 Fe を同時炕与 之たならば恐らく $\mathrm{Hb}$ もく增加するものと考之， 前編での成績から最もよく骨㘍䌈胞化利用される形 と考えられるクルコン厒第 2 鉄を同時に添加してみ た. 結果は果して赤血球の增加と共に $\mathrm{Hb}$ 量增加 る著しく、特に鉄とコハルルト量比を1：50亿して 添加した場合が著明であつた。但し同じ 1：50の比 飞加六てもク. $1 \mathrm{mg}$ とコ. $50 \mathrm{mg}$ の如く、コハルト の㫣が多くなるととの金属イオンの垡性のたる却つ て增沿が障害さ机る。

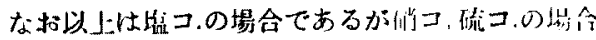
はその分子虫が大であるからグに100借の比に机え た場合にるよく增血を起す。而して以上の場合クの 単独或は血清と共飞添加した際の $\mathrm{Hb}$ 增加冒を遥 かにしのく甚しいHb 增加が見られることから， Co 飞社鉄の Hem への合成を強力几促進する作用 の存することが考えられる。

な敃硝コ., 硫コ.とグ.を合併した際の赤血球增加が 之等を単独或俚血清と共に添加した際の赤血球增加 そ比して著しく大でない原因はやはり恐らくは全属 
イオンの增加による障害が幾分おらわれるためであ ろ5.

次に前編に於て単独添版て最す增血効果の恶かつ た磁酸第 1 鉄はやはり Co と合併添加してb著明

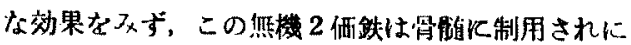
くい班であることを更に裹曹きした。

次に銅の添州実験成績について考按する，既述の 如く, 銅の增血作用は古くから知られているが珠に 近年鉄の補血作用上，銅の極めて重要なことが判明 してきた，古く Schult268) 等は銅は赫血球形成に 対して刺戟を与え，かつ鉄の存在を俟つて $\mathrm{Hb}$ の形 成に与るすのならんと述へてでり，近時その機転に 関しては Granick17) 等により,銅は鉄の Protoporphyrin 環への逶入の触媒として働くものであると いわ机ている.な㕲又銅は生体内に於て Cytochrome A, Cytochrom Oxydase, Katalase 等の形成に重要 な役目を有することが知られて打り，之も銅の血色 装增生の機序の一面をなすものであるうことが考え られる. 又最近 Wintrobe6)7) 等は白国等の実験に 於ける銅欠之時の角血で銅剂を投与すると腸管に於 ける鉄の吸収が促進されることを見ている。

さて私の実験に於ては単独添加では硫䣼銅，塩化 銅洪に赤血球增加任用はなく，鉄、コパルよりる 胃骮积胞に対する毒性が强いことが分かつた。しか し少冒添加では殊に程化銅に於てかなりの $\mathrm{Hb}$ 增 扣を諗めた．しかし血清を添加するもこの効果と影 然はなかつたが，グを同時に与えるならほ赤血球は 依然減少するが Hb 量は著明飞增大乙，銅或いは グの笪独添加の際の增加量を越えたのでやはり銅 は䧃胞の鉄の利用を助長することが確められた。

次に鉄，コバルト，銅の3者を同時に添加したと ころ，かなり著明な増血作用を涊めたが，既述の如 き鉄，銅の合併或は鉄、コバルトの合併添加で見ら れる程の著しい增搵效黑はなく、結局金屈イオンの 品の增大が細胞に障害を与えるものと考えられ，各

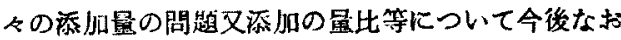
蚞討の余地が残されている。

\section{第 9 羑赫語}

1）家鬼骨榷組織液体培䖭法によりコバルト及び 銅を単独或は鉄と合併して忝加しその增血效果を㭘 討した。

2）コハルト単独添加では，㙁化コパルトを除き いうれる著明な赤血球增多を起すが，Hb 量は却つ て減少する場合が多い，而してこの低色性增血作用
の原因は鉄の供給不足にあるすのと考えられる，

3）グルコン酸 2 鉄と同時にコバルトを添加す れば Hb 畺は極めて著明に堌加し，殊にグルコン 酸第 2 跌と㳑化コパトを 1:50 の比に加えた場 合に著しく、コバルが鉄の Hem 核への薄入を弶 く敁持することが示唆された。

4）銅は単独添加でる，鉄と合併してるその参属 毒性が強く赤血球增加を起さないが，鉄と合併した 場合には Hb 睴が著しく增加し，やはり銅はコパ ルトと同様，鉄の Hb 構成を促進することが認め られた.

5）鉄,銅，コバルトの 3 者併用添加は最大の効 果を示さず，その添加量に金属毒性の問題を考感す る必要があると考沈る。

\section{全絰 の 粘 括}

1）1936年 Osgood そより創始せられた骨榷組䋚 液体培養法はその後 Hays, Norris \& Majnarichi, 伊藤，牧野等により装法が考案され，種々の物質を 直接骨髄に添加してその堌血機能に及ほす影響が検 討されている，私は教室に於ける骨涟組織培善研究 の一端として鉄，銅，コバルト塩類の直接骨睢赤血

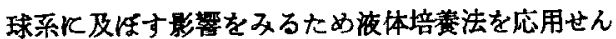
としたが，諸氏により発表された従来の方法に於て 骨䯋採取方法，細胞浮游液作製法等になお改良すへ き点を見出し，種々工夫検討の結果，次の改良法を 考案した，即ち家鬼を屡籼後直ちにその四肢骨を剔 出し，骨錯子で注意深く骨を割りその全骨髄をとり Glucose free の Tyrode氏液で洗涤後之をホモグナ イザーにかけ低速で破砵した。これにより末梢血の 淈入を最小限度に抑えて均等な骨髄浄胞浮游液をつ くることに成功した，な招培地としては Gey 氏第 II液を用い，Warburg 氏恒温槽で振㑔垶资し 4 時 閉及び 8 時間後のデー夕をとつた。

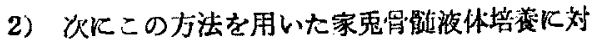
し無機，有機の 2 洒鉄及び 3 価銠を添加し，その增 血作用を稓察した，結果は有機 3 䛧鉄たるクルコン 酸第 2 銠が最す增血効果がよく，珠值清を合併添 加すると Hb 置の著しい增加をみ，鉞の Hem 核 への噵入には血清中の因子の必要なることを知つた。 乙かし同じ有機 3 佂鉄のクエン酸鉄アンモンには単 独或は血清の合併添加ですみるべき堌血效果がなく， 又無価の硫酸第 1 鉄と無機 3 洒の塩化第 2 鉄と の増血効果には著しいものがなく，両者の差も認め られなかつた，更に無機 3 価鉄の塭化第 2 鉄と有嘰 


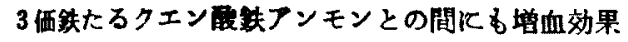

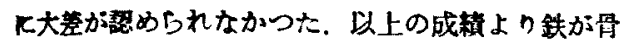

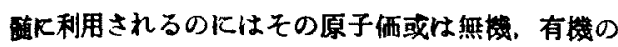
差よりもしろ鉄の化合物の形か関与するすのと考 充られら.

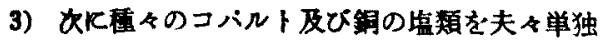
或は鉄と合湖して添加した. 先づコバルト筆独添加 て煋化コハハトを除き何れる明らかな赤血球增多 を起すが，Hb 擂は却つて减少する場合が多く，更

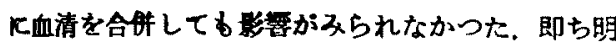
らかな低色性の堷血勃果を認めたのであるが，その 原因鉄の供站不足によるるのではなかるうかと考 えかにコハルトと共に鉄を合併して添加した。䊅 果は果して慕加量が適当であれば赤血球数， Hb 量 共によく增加し，特にクルコン酸第 2 鉄を塩化コパ ルトK合併しその量比を $1: 50$ にして添加した坦 合が最あ著明であつた，而してこの場合の Hb 增 加軎はクルコン酸第 2 鉄単独，或は之と血清を合所

文

1) Barkan, G.: Hoppe-Seylers Z., 177, 205, 1928.

2) Barron, A.G., S. G. Barron Proc. Exp. Biol. Med., 35, 407, 1935 1936.

3) Bucciero, M. C., J. M. Orten Blood, 4, $395,1949$.

4) Carrel, A., I. T. Burrows J. A. M. A.. 55, 1379, 1910.

5) Carrel, A., M. T. Burrows J. Exp. Med., 13, 387, 1911.

6) Csrtwright, G. E. et al. J. Clin. Inv.. 32, 405, 1953.

7) Cartwright, G. E., et al. . Am. J.Clin. Natr., 3, 11, 1955.

8) Desehamps Ann. Hyg. publ. PARIS, 41, 219, 1849.

9) Devergie, A., Hervey, O. : Ann. Hyg. publ. PARIS, 20, 463, 1838.

10) Erdmann, R. . Proc. Soc. Exp. Biol. Med., 15, 96, 1917.

11) Erdmann, R.: Am. J. Anat., 22, 73, 1917.

12) Fischer, A.: J. Exp. Med., 35, 367, 1922.

13) Foot, M. D. : Beitr. zur. Path. Anat. u. zur. Allg. Pathol., 53, 446, 1912.

14) 福井定光他：日血会誌，16，4，59，昭28.
して添加した場合の增加量を䧟かに淩ぎ、コハルト が铁の Hem 核への導入を強く支持することが示惨 ent.

4）次に銅はその金屈イオン毒性が㧧く，単独添 加，血清との合併添师，更に鉄との合併添加の何れ の埸合にる赤血球增加は起らないが， Hb 量のみは 鉄と合併した場合に着しく增加し，銅もコハルトと 同しくく鉄の Hb 粠成を促進することが認められた。

5）加に鉄，銅，コハルトの3者を问時に添加し てみたが，最大の効果を示さお゙，之には添加量の增 加化伴う金属毒性の問題を考虑する必要がある.

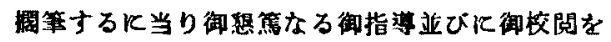
晹つた恩師平木教授及び大葆助教授に対し深甚の謝 倠を表す。

（本稿の要旨は第17囘日本血液学全総会及び第11 回中四国内科学会に於て発表した）

\section{都}

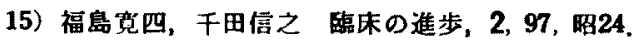

16) Gey, G. O., Gey, M. K. : Am. J. Cancer, 27, 45, 1936.

17) Granick, S. . J. Biol. Chem., 164, 737, 1946,

18) Grossmann, W.: Beitr. zur. Path. Anst. u. zur. Allg. Pathol, 721, 195, 1924.

19) Harrison, R. G.: Proc. Soc. Exp. Biol. Med., 4, 140, 1907.

20) Harque, M. C. et al. J. Biol. Chem., 78, 1928.

21）長谷川弥人：内科最近の進歩，I，43，昭31.

22）長谷川吉䐂：日血会誌，17，4５，49，昭29。

23）服部陖治郎：実験医報，20，3，418，昭 8 .

24) Hays, E. E. . Proc. Soc. Exp. Biol. Med., $63,558,1946$.

25) Hays, E. E. Am. J. Med. Sci., 216, 528, 1948.

26) Heilmeyer, L. Das Serumeisen u. die Eisenmangelkrankheit, Jema. Gustav. Fischer, 1937.

27) Heabner, W. Heffters Handb. d. Exp. Pharm., III/2, 621, 1934.

28）猪野退分：日血会譩，17，30，昭29.

29）井上茂治：大婜医事新誌原著版，6，1，1，四10.

30）井上寒都治：東北医学会誌，21，2，105, 昭12. 
31) Inoue, J., F. B. Flinn : J.A.M.A. 90, 1928.

32) Isräel̨s, M, C, G. . J. Path. Bact., 51, 235, 1940.

33）仢藤声次: Vitamin，5，5，28，昭27.

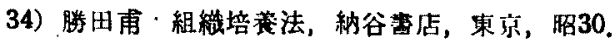

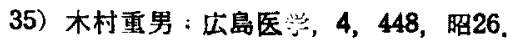

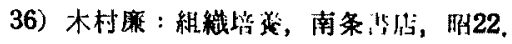

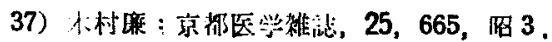

38) Kleinberg, W. This Journal, 108, 545, 1934.

39）小池五郎 血液討譜会報告，5，71，昭28。

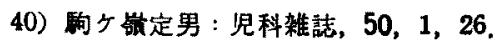

41）小松周治：日微病会誌，25，337，昭 6 .

42）綝野邦夫生化学，26，3，1，昭29.

43）国延益弘阔山医学会婄，67，7１2，73，昭31.

44) Lew is, M. R., W. H. Lewis : J. A. M. A., 56, 1795, 1911.

45) Lintzel, W. Z. Biol., 83, 289, 1925.

46）牧野秀夫 Vitamin，4，450，腿26。

47) Mann, T., Keilin, D. : Proc. Roy. Soc., B. 126, 303, 1938 .

48) Mascherpa, P. : A rch. Ital. Biol., 82, 112. 1930.

49) Maximov, A.: Arch. f. Mik. Anat., 96, 494, 1922.

50）中尾要久：最新医，7，165，摞27.

51) Nissin, J. A... Lancet, 49, 1947.

52) Norris, E. R., Majnarichi, J.J. Am.J. Phisiol., 152, 175, 1948.

53) Norris, E. R., Majnarichi, J.J. Am. J. Phisiol., 153, 496, 1948.

54）大藤真：最新医，10，12，106，础30。

55）大藤真：最新医学，11，2，153，昭31.

56）大藤真 : 日内会誌, 43, 925, 昭 30.

57）小川三郎：日血会㣟，17，4〜5，50，明29.

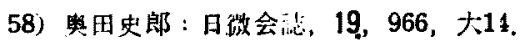

59) Osgood, E. E., Muscovitz, A. N. . J.A.M.A. 106, 1888, 1936.

60) Osgood, E. E., Brownlee, I. F. : J.A.M.A. 107, 123, 1936.

61) Osgood, E. E., Brownlee, I. E. . J.A.M.A. 108, 1793, 1937.

62) Orten, J. M. : Am. J. Phisiol., 114, 414, 1935.

63) Rickes \& Brink: Science, 108, 134, 1948, Zitr, «. Suzuki.

64) Roux, V.W.: Zitr. n. Okuda.

65）圾井藤吉：東北医学雑誌，24，441，562, 昭14.

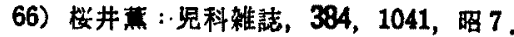

67) Schilling, V.: Das Blutbild, Jema, Gustar. Fischer, 1935.

68) Schultze, K. W. . Kl. W., 12, 497, 1932.

69）妺尾左千丸：血液討議会㫰告，I，54，昭23.

70）妹尾古下儿·細胞化学ンンポジム，I，55, 凅28.

71）島什敏夫：綜合医学，10，3，112，昭28。

72）帛田敏夫，吉野秀夫：綜合医学，12，835，昭29.

73) Slack et al. : Lancet, 259, 11, 1949.

74) Stare, F. J., C. A. Elvehjem : J. Biol. Chem., 19, 473, 1932 33.

75) Starkenstein, E. : Arch. f. Exp. Path., 134, 288, 1928 .

76) Starkenstein, E. : Arch. f. Fxp. Path. u. Pharm., 127, 101, 1927.

77) Stockmann, R. : Brit. Med. J., 881, 1893.

78) Sutter, J. Compt. rend. Soc. biol., 116, 994, 1934.

79）鈴木泰三：日本生理学会就，13，1２，102， 昭26.

80）鈴木泰三：Tohoku. J. Exp. Med., 52, 1 2, $102,1950$.

81）鈴木泰三: Tohoku. J. Exp. Med., 53, 3 4, $367,1951$.

82）跑石权 . 日医新埌，1534，3664，1535，3756， 略28.

83) Titus, R. V. et al.: J. Biol. Chem., No. 80, 1928.

84) Töttermann Zitr. n. Nakao, 日血会誌, 17, 4 5, 47, 昭29.

85) Tsumaki Bull. Chem. Soc. Japan, 13, 252, 1938.

86) Underhill, F.A., J.A. Orten, R.C. Lewis : J. Biol. Chem., No. 91, 1931.

87) Vannoti . 7. Exp. Med., 108, H. 3, 336, 1940.

88) Waddel et al. : J. Biol. Chem., 72, No. 1927, No. 77, 1928, No. 83, 1929.

89) Waltner, K., K. Waltner - Klin. Wschr., 8, 313, 1929.

90) Watson, C. J.: Downey's Handbook of Haematology, III, 2445, 1938.

91）安川星三，日病会誌，32，220，昭17. 


\title{
Hematopoietic Action of Iron, Copper and Cobalt by Rabbit Bone Marrow Tissue Culture in Fluid Medium
}

\section{Part 2 Hematopoietic Actions of Cobalt and Copper}

\author{
By

\section{Katsuya Kumeda} \\ Department of Internal Medicine Okayama University Medical School \\ (Director : Prof. Kiyoshi Hiraki)
}

1. Hematopoietic actions of cobalt and copper, either singly or in combination with iron have been studied by means of rabbit bone marrow culture in fluid medium.

2. When various cobalt compounds are added singly, with exception of cobalt chloride, every one of them acts markedly to help erythropoiesis, but $\mathrm{Hb}$ content on the contrary often decreases by such addition. Consequently, this hypochrome erythropoiesis seems to be due to lack of iron supply.

3. In the case where ferric gluconate is added in combination with cobalt compounds, $\mathrm{Hb}$ increses markedly, especially $\mathrm{so}$ when the combination is ferric gluconate and cobalt chloride in proportion of 1:50; suggesting that cobalt greatly assists the induction of iron into the heme nucleus.

4. Due to its toxicity, copper addition either singly or in combination with iron does not help erythropoiesis to any great extent, but when in combination with iron as in the case of cobalt copper helps to increase $\mathrm{Hb}$ content.

5. The addition of three metals, iron, copp3r, and cobalt, doss not yield the best result, indicating the necessity of giving a consideration to the toxicity arising out of the amount to added. 